\title{
LEVEL II SCOUR ANALYSIS FOR BRIDGE 23 (GLOVTH00410023) on TOWN HIGHWAY 41, crossing SHERBURNE BROOK, GLOVER, VERMONT
}

U.S. Geological Survey Open-File Report 97-388

Prepared in cooperation with

VERMONT AGENCY OF TRANSPORTATION and

FEDERAL HIGHWAY ADMINISTRATION 


\section{LEVEL II SCOUR ANALYSIS FOR BRIDGE 23 (GLOVTH00410023) on TOWN HIGHWAY 41, crossing SHERBURNE BROOK, GLOVER, VERMONT \\ By SCOTT A. OLSON and ERICK M. BOEHMLER}

U.S. Geological Survey Open-File Report 97-388

Prepared in cooperation with

VERMONT AGENCY OF TRANSPORTATION and

FEDERAL HIGHWAY ADMINISTRATION 


\title{
U.S. DEPARTMENT OF THE INTERIOR BRUCE BABBITT, Secretary
}

\author{
U.S. GEOLOGICAL SURVEY \\ Gordon P. Eaton, Director
}

For additional information write to:

District Chief

U.S. Geological Survey 361 Commerce Way

Pembroke, NH 03275-3718
Copies of this report may be purchased from:

U.S. Geological Survey

Branch of Information Services

Open-File Reports Unit

Box 25286

Denver, CO 80225-0286 


\section{CONTENTS}

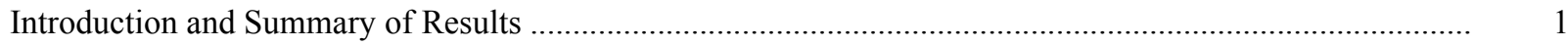

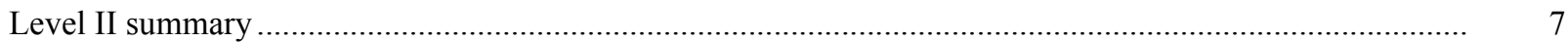

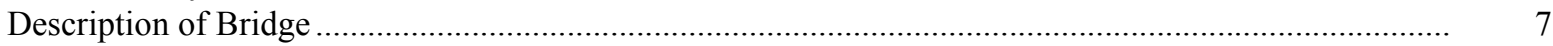

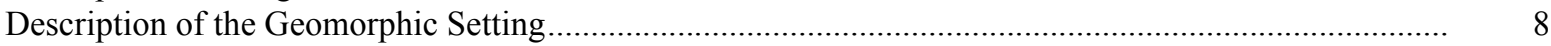

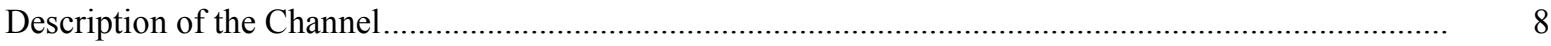

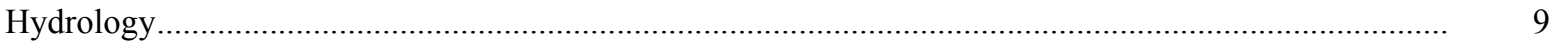

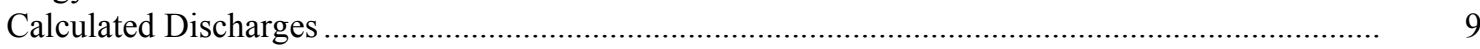

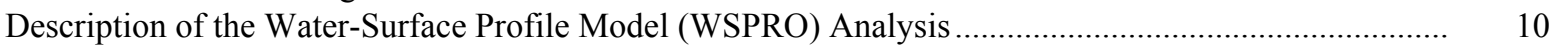

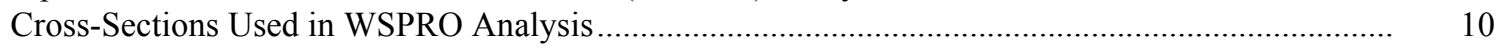

Data and Assumptions Used in WSPRO Model ..................................................................... 11

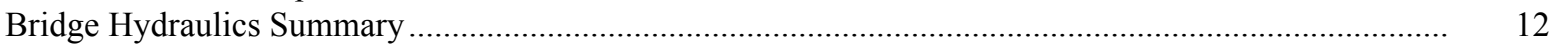

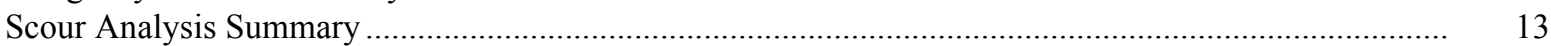

Special Conditions or Assumptions Made in Scour Analysis ...................................................... 13

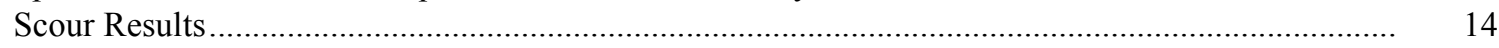

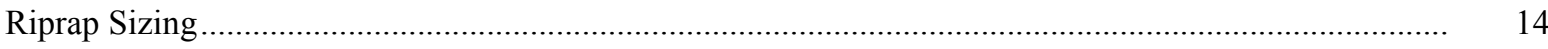

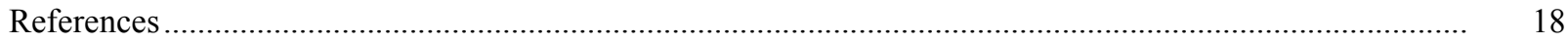

Appendixes:

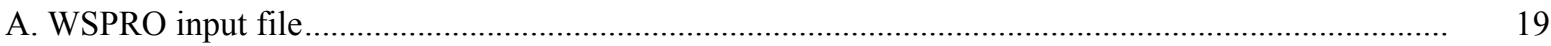

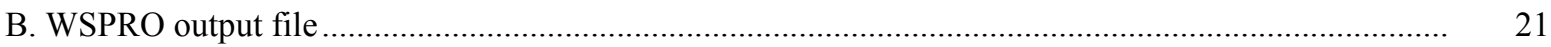

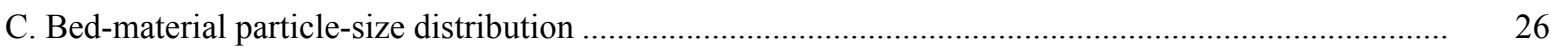

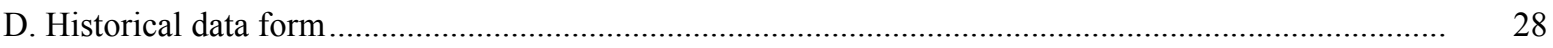

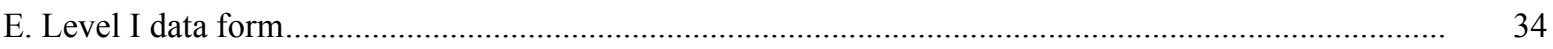

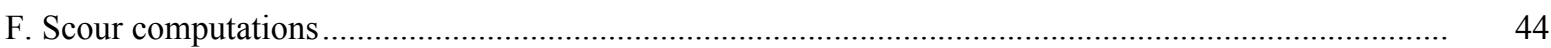

\section{FIGURES}

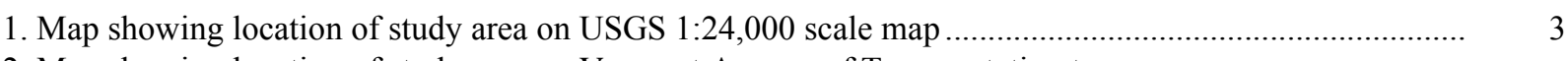

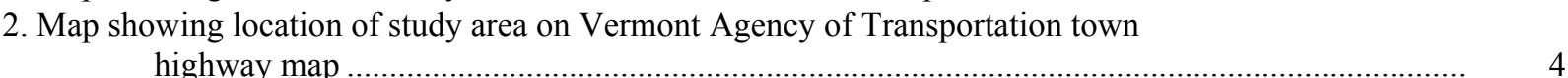

3. Structure GLOVTH00410023 viewed from upstream (October 25, 1994) ............................................ 5

4. Downstream channel viewed from structure GLOVTH00410023 (October 25, 1994). ......................... 5

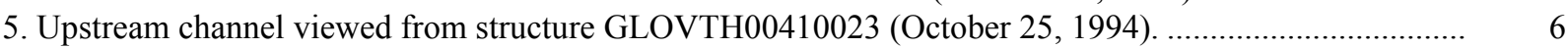

6. Structure GLOVTH00410023 viewed from downstream (October 25, 1994)...................................... 6

7. Water-surface profiles for the 100- and 500-year discharges at structure

GLOVTH00410023 on Town Highway 41, crossing Sherburne Brook,

Glover, Vermont.

8. Scour elevations for the 100- and 500-year discharges at structure

GLOVTH00410023 on Town Highway 41, crossing Sherburne Brook,

Glover, Vermont.

\section{TABLES}

1. Remaining footing/pile depth at abutments for the 100-year discharge at structure

GLOVTH00410023 on Town Highway 41, crossing Sherburne Brook,

Glover, Vermont

2. Remaining footing/pile depth at abutments for the 500-year discharge at structure

GLOVTH00410023 on Town Highway 41, crossing Sherburne Brook,

Glover, Vermont

3
4
5
5
6
6




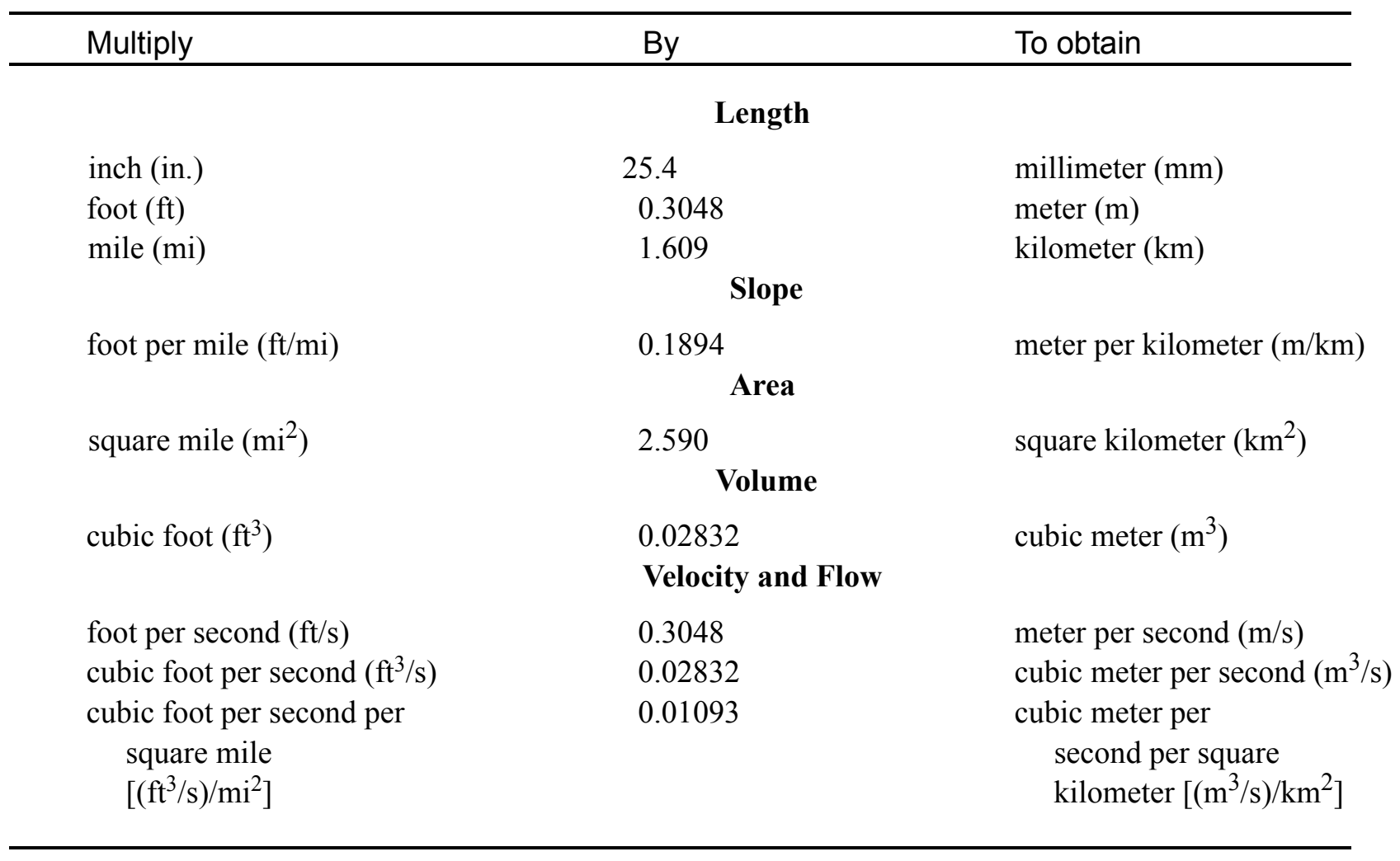

\section{OTHER ABBREVIATIONS}

$\begin{array}{lrlr}\mathrm{BF} & \text { bank full } & \text { LWW } & \text { left wingwall } \\ \mathrm{cfs} & \text { cubic feet per second } & \text { MC } & \text { main channel } \\ \mathrm{D}_{50} & \text { median diameter of bed material } & \text { RAB } & \text { right abutment } \\ \mathrm{DS} & \text { downstream } & \text { RABUT } & \text { face of right abutment } \\ \mathrm{elev} & \text { elevation } & \text { RB } & \text { right bank } \\ \mathrm{f} / \mathrm{p} & \text { flood plain } & \text { ROB } & \text { right overbank } \\ \mathrm{ft}^{2} & \text { square feet } & \text { RWW } & \text { right wingwall } \\ \mathrm{ft} / \mathrm{ft} & \text { feet per foot } & \text { TH } & \text { town highway } \\ \mathrm{JCT} & \text { junction } & \text { UB } & \text { under bridge } \\ \mathrm{LAB} & \text { left abutment } & \text { US } & \text { upstream } \\ \mathrm{LABUT} & \text { face of left abutment } & \text { USGS } & \text { United States Geological Survey } \\ \mathrm{LB} & \text { left bank } & \text { VTAOT Vermont Agency of Transportation } \\ \mathrm{LOB} & \text { left overbank } & \text { WSPRO } & \text { water-surface profile model }\end{array}$

In this report, the words "right" and "left" refer to directions that would be reported by an observer facing downstream. Sea level: In this report, "sea level" refers to the National Geodetic Vertical Datum of 1929-- a geodetic datum derived from a general adjustment of the first-order level nets of the United States and Canada, formerly called Sea Level Datum of 1929.

In the appendices, the above abbreviations may be combined. For example, USLB would represent upstream left bank. 


\title{
LEVEL II SCOUR ANALYSIS FOR BRIDGE 23 (GLOVTH00410023) ON TOWN HIGHWAY 41, CROSSING SHERBURNE BROOK, GLOVER, VERMONT
}

\author{
By Scott A. Olson and Erick M. Boehmler
}

\section{INTRODUCTION AND SUMMARY OF RESULTS}

This report provides the results of a detailed Level II analysis of scour potential at structure GLOVTH00410023 on Town Highway 41 crossing Sherburne Brook, Glover, Vermont (figures 1-8). A Level II study is a basic engineering analysis of the site, including a quantitative analysis of stream stability and scour (U.S. Department of Transportation, 1993). Results of a Level I scour investigation also are included in Appendix E of this report. A Level I investigation provides a qualitative geomorphic characterization of the study site. Information on the bridge, gleaned from Vermont Agency of Transportation (VTAOT) files, was compiled prior to conducting Level I and Level II analyses and is found in Appendix D.

The site is in the New England Upland section of the New England physiographic province in northern Vermont. The $2.57-\mathrm{mi}^{2}$ drainage area is in a predominantly rural and forested basin. In the vicinity of the study site, the surface cover is primarily forest with small areas of lawn and a home on the right overbank and a gravel roadway along the upstream left bank.

In the study area, Sherburne Brook has an incised, sinuous channel with a slope of approximately $0.03 \mathrm{ft} / \mathrm{ft}$, an average channel top width of $33 \mathrm{ft}$ and an average bank height of $6 \mathrm{ft}$. The channel bed material ranges from gravel to boulder with a median grain size $\left(D_{50}\right)$ of $57.3 \mathrm{~mm}(0.188 \mathrm{ft})$. The geomorphic assessment at the time of the Level I and Level II site visit on October 24, 1994, indicated that the reach was stable.

The Town Highway 41 crossing of Sherburne Brook is a 24-ft-long, one-lane bridge consisting of one 21-foot steel-beam span with a timber deck (Vermont Agency of Transportation, written communication, August 4, 1994). The opening length of the structure parallel to the bridge face is $20.3 \mathrm{ft}$. The bridge is supported by vertical, granite block abutments. The channel is skewed approximately 55 degrees to the opening while the measured opening-skew-to-roadway is 30 degrees.

One foot of scour below the mean thalweg depth was observed along the right abutment undermining the abutment by 0.5 feet vertically. Additional details describing conditions at the site are included in the Level II Summary and Appendices D and E. 
Scour depths and recommended rock rip-rap sizes were computed using the general guidelines described in Hydraulic Engineering Circular 18 (Richardson and others, 1995). Total scour at a highway crossing is comprised of three components: 1) long-term streambed degradation; 2) contraction scour (due to accelerated flow caused by a reduction in flow area at a bridge) and; 3 ) local scour (caused by accelerated flow around piers and abutments). Total scour is the sum of the three components. Equations are available to compute depths for contraction and local scour and a summary of the results of these computations follows.

Contraction scour for all modelled flows ranged from 0.4 to $0.8 \mathrm{ft}$. The worst-case contraction scour occurred at the 500-year discharge. Abutment scour ranged from 4.6 to $7.2 \mathrm{ft}$. The worst-case abutment scour also occurred at the 500-year discharge. Additional information on scour depths and depths to armoring are included in the section titled "Scour Results". Scoured-streambed elevations, based on the calculated scour depths, are presented in tables 1 and 2. A cross-section of the scour computed at the bridge is presented in figure 8. Scour depths were calculated assuming an infinite depth of erosive material and a homogeneous particle-size distribution.

It is generally accepted that the Froehlich equation (abutment scour) gives "excessively conservative estimates of scour depths" (Richardson and others, 1995, p. 47). Usually, computed scour depths are evaluated in combination with other information including (but not limited to) historical performance during flood events, the geomorphic stability assessment, existing scour protection measures, and the results of the hydraulic analyses. Therefore, scour depths adopted by VTAOT may differ from the computed values documented herein. 


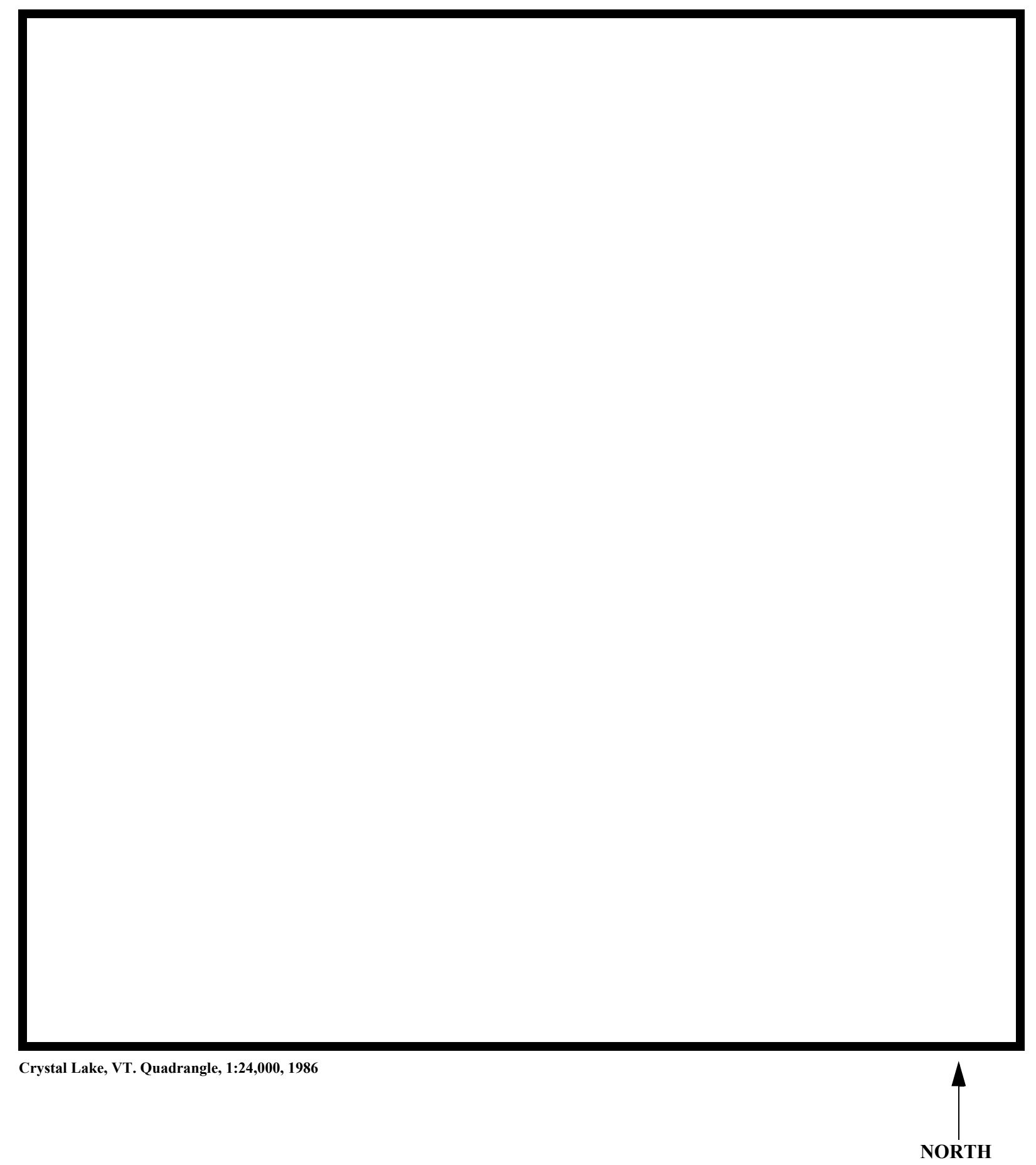

Figure 1. Location of study area on USGS 1:24,000 scale map. 
Figure 2. Location of study area on Vermont Agency of Transportation town highway map. 

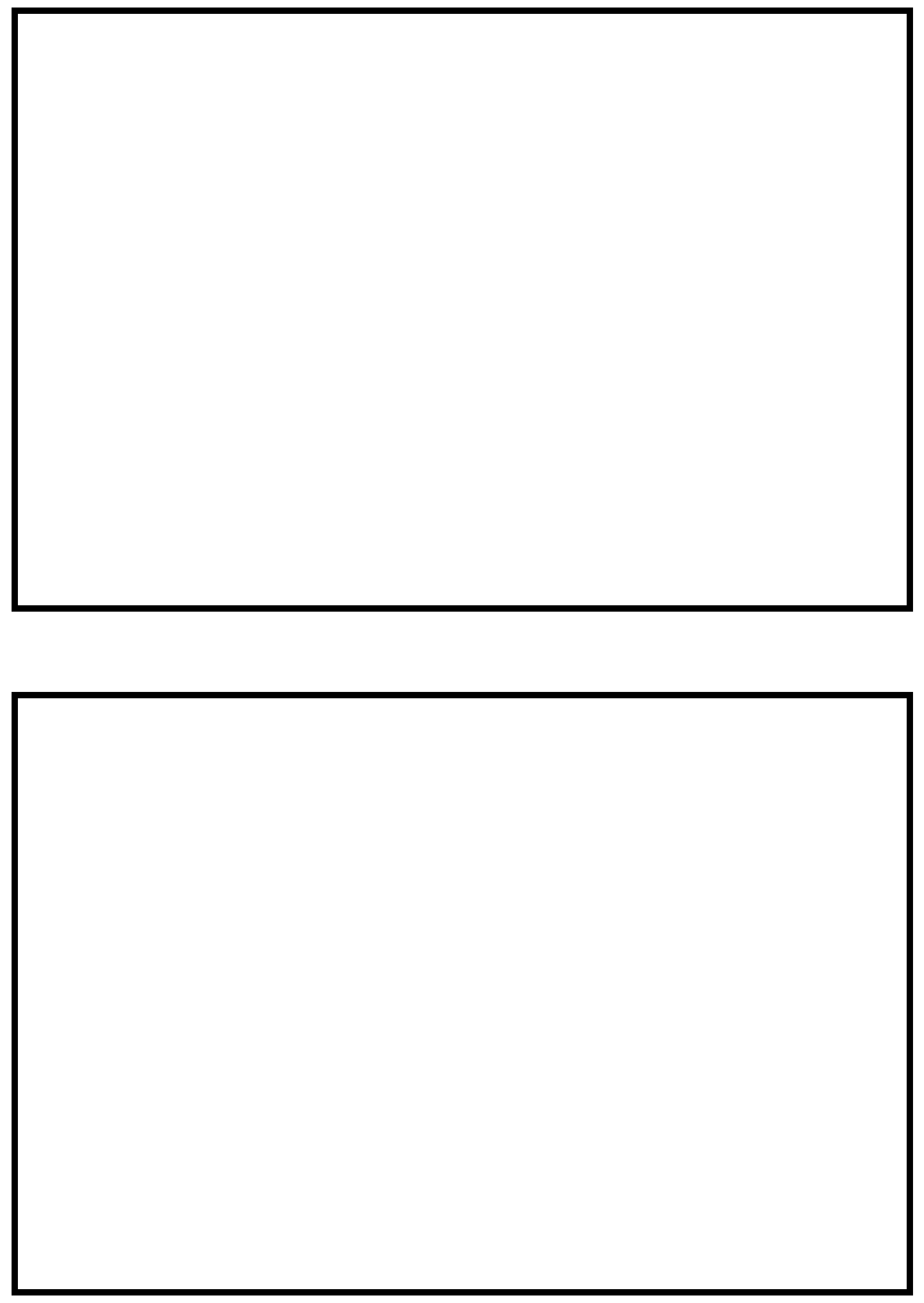

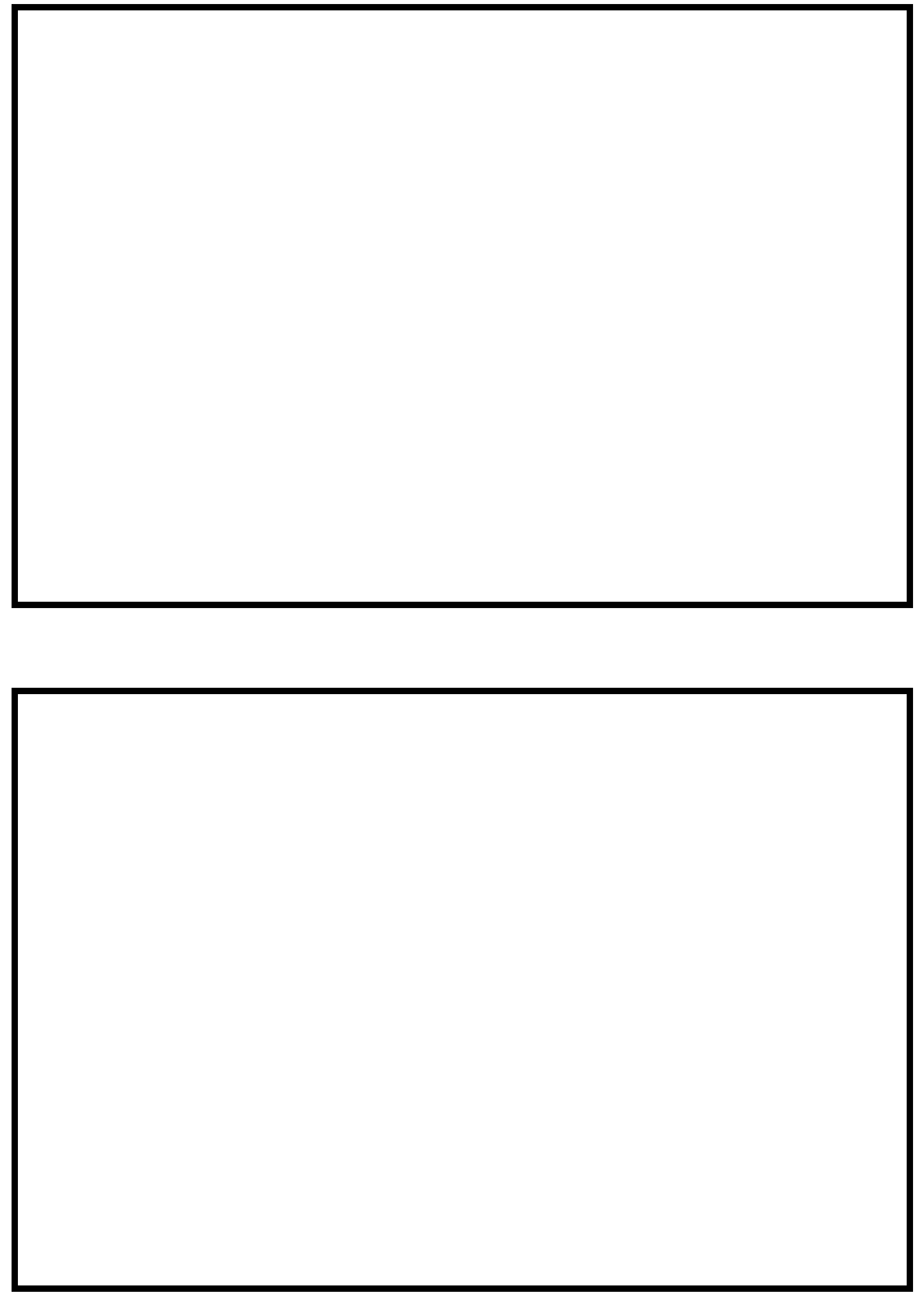


\section{LEVEL II SUMMARY}

\begin{tabular}{llllll} 
Structure Number & GLOVTH00410023 & & \multicolumn{3}{c}{ Sherburne Brook } \\
Stream & & & & \\
County & Orleans & Road & TH41 & District & 9
\end{tabular}

\section{Description of Bridge}

Bridge length $\stackrel{24}{-} \boldsymbol{f t}$ Bridge width $\frac{14.5}{f t}$ Max span length $\stackrel{21}{ } \boldsymbol{f t}$ Alignment of bridge to road (on curve or straight)

\begin{tabular}{|c|c|c|c|}
\hline \multirow{2}{*}{ Abutment type } & , granite & \multirow{3}{*}{$\begin{array}{l}\text { Embankment type } \\
\text { Dato af incnortion }\end{array}$} & None \\
\hline & No & & $10 / 24 / 94$ \\
\hline Stone fill on abutment? & & & \\
\hline
\end{tabular}

Abutments are constructed of granite blocks and extend 11 and $31 \mathrm{ft}$ upstream on the respective left and right sides. The right abutment is undermined 0.5 $\mathrm{ft}$.

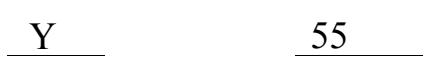

Is bridge skewed to flood flow according to Y r survey? Angle

There is a severe channel bend at the channel entrance to the bridge. Scour has developed in the location where the bend impacts the right abutment.

Debris accumulation on bridge at time of Level I or Level II site visit:

\begin{tabular}{|c|c|c|c|}
\hline & $\begin{array}{c}\text { Date of insmortion } \\
\underline{10 / 24 / 94}\end{array}$ & $\begin{array}{l}\text { Percent of almmust } \\
\text { blocked inortzontatly }\end{array}$ & $\begin{array}{l}\text { Percent of } 0 \\
\text { blocked verticatty }\end{array}$ \\
\hline Level I & $10 / 25 / 94$ & 0 & 0 \\
\hline & Moderate. & & \\
\hline
\end{tabular}

Potential for debris

$10 / 24 / 94,--$.

Doscriho anv, foaturos noar ar at tho hridos that mav, affoct flou, (includo ahsorvation dato) 


\section{Description of the Geomorphic Setting}

General topography The channel is located within a narrow, high relief valley. There are no

flood plains.

Geomorphic conditions at bridge site: downstream (DS), upstream (US)

Date of inspection $\quad 10 / 24 / 94$

DS left: $\quad$ Steep channel bank and steep valley wall.

DS right: $\quad$ Narrow terrace to steep valley wall.

US left: $\quad$ Steep channel bank, roadway, and steep valley wall.

US right: $\quad$ Steep channel bank, narrow terrace, and steep valley wall.

\section{Description of the Channel}

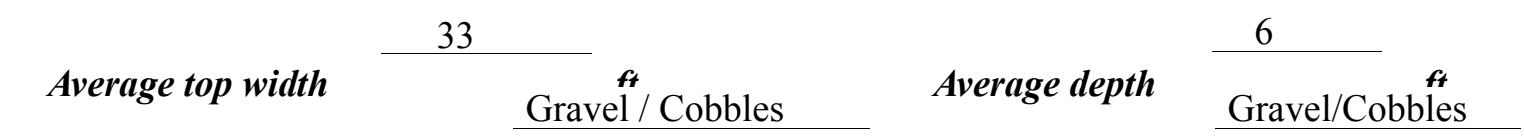

Predominant bed material

Bank material Sinuous but stable

with semi- to non-alluvial channel boundaries and no flood plains.

$10 / 24 / 94$

Vegetative co 1 Trees and brušh.

DS left: $\quad$ Trees and brush with a small area of lawn on the overbank.

DS right: $\quad$ Trees and brush with a gravel roadway on the immediate channel bank.

US left: $\quad$ Trees and brush with a small area of lawn and a home on the overbank.

US right: $\quad$ Y

Do banks appear stable? -

y mus, ме

date of observatton.

None, 10/24/94.

Describe any obstructions in channel and date of observation. 


\section{Hydrology}

Drainage area $\stackrel{2.57}{\mathbf{m i}} \mathbf{i}^{2}$

Percentage of drainage area in physiographic provinces: (approximate)

Physiographic province/section New England/New England Upland
Percent of drainage area 100

Is drainage area considered rural or urban? — Rural _ Describe any significant urbanization:

Is there a USGS gage on the stream of interest?

No

USGS gage description

USGS gage number

Gage drainage area $\mathrm{mi}^{2}$

Is there a lake/p

515 Q100 $\quad \mathrm{ft}^{3} / \mathrm{s}$

Calculated Discharges

700

Q500 $\quad \mathrm{ft}^{3} / \mathrm{s}$

The 100- and 500-year discharges were the median

values from flood frequency curves developed from several empirical methods (Benson, 1962;

Johnson and Tasker, 1974; FHWA, 1983; Potter, 1957a\&b; Talbot, 1887). 


\section{Description of the Water-Surface Profile Model (WSPRO) Analysis}

Datum for WSPRO analysis (USGS survey, sea level, VTAOT plans)

USGS survey

Datum tie between USGS survey and VTAOT plans

None

Description of reference marks used to determine USGS datum. $\quad$ RM1 is a chiseled

square on top of the abutment footing directly below the upstream right corner of the bridge

deck (elev. $93.30 \mathrm{ft}$, arbitrary survey datum). RM2 is a chiseled square in the top of the

abutment footing directly below the downstream right corner of the bridge deck (elev. $93.13 \mathrm{ft}$,

arbitrary survey datum).

\section{Cross-Sections Used in WSPRO Analysis}

\begin{tabular}{cccl}
\hline${ }^{1}$ Cross-section & $\begin{array}{c}\text { Section } \\
\text { Reference } \\
\text { Distance } \\
\text { (SRD) } \text { in feet }\end{array}$ & $\begin{array}{c}{ }^{2} \text { Cross-section } \\
\text { development }\end{array}$ & \multicolumn{1}{c}{ Comments } \\
\hline EXITX & -34 & 1 & $\begin{array}{l}\text { Exit section } \\
\text { Downstream Full-valley } \\
\text { section (Templated from } \\
\text { EXITX) }\end{array}$ \\
BRIDG & 0 & 2 & $\begin{array}{l}\text { Bridge section } \\
\text { Road Grade section }\end{array}$ \\
RDWAY & 0 & 1 & $\begin{array}{l}\text { Modelled Approach sec- } \\
\text { tion (Templated from } \\
\text { APPRO }\end{array}$ \\
& 8 & 1 & $\begin{array}{l}\text { APTEM) } \\
\text { Approach section as sur- } \\
\text { veyed (Used as a tem- } \\
\text { plate) }\end{array}$ \\
\hline
\end{tabular}

${ }^{1}$ For location of cross-sections see plan-view sketch included with Level I field form, Appendix E.

For more detail on how cross-sections were developed see WSPRO input file. 


\section{Data and Assumptions Used in WSPRO Model}

Hydraulic analyses of the reach were done by use of the Federal Highway Administration's WSPRO step-backwater computer program (Shearman and others, 1986, and Shearman, 1990). The analyses reported herein reflect conditions existing at the site at the time of the study. Furthermore, in the development of the model it was necessary to assume no accumulation of debris or ice at the site. Results of the hydraulic model are presented in the Bridge Hydraulic Summary, Appendix B, and figure 7.

Channel roughness factors (Manning's " $n$ ") used in the hydraulic model were estimated using field inspections at each cross section following the general guidelines described by Arcement and Schneider (1989). Final adjustments to the values were made during the modelling of the reach. Channel " $n$ " values for the reach ranged from 0.045 to 0.055 , and overbank " $\mathrm{n}$ " values ranged from 0.035 to 0.095 .

Normal depth at the exit section (EXITX) was assumed as the starting water surface. This depth was computed by use of the slope-conveyance method outlined in the user's manual for WSPRO (Shearman, 1990). The slope used was $0.029 \mathrm{ft} / \mathrm{ft}$ which was computed from surveyed thalweg points downstream of the bridge.

The surveyed approach section (APTEM) was moved along the approach channel slope $(0.0038 \mathrm{ft} / \mathrm{ft})$ to establish the modelled approach section (APPRO), one bridge length upstream of the upstream face as recommended by Shearman and others (1986). This location also provides a consistent method for determining scour variables.

For the 500-year discharge, WSPRO assumes critical depth at the bridge section. A supercritical model was developed for this discharge. After analyzing both the supercritical and subcritical profiles, it can be determined that the water surface profile does pass through critical depth within the bridge opening at the 500-year discharge. Thus, the assumption of critical depth at the bridge is a satisfactory solution. 


\section{Bridge Hydraulics Summary}

\begin{tabular}{llll} 
Average bridge embankment elevation & 99.6 & $f t$ \\
\cline { 3 - 3 } Average low steel elevation & 98.0 & $f t$
\end{tabular}

100-year discharge $\quad 515 \quad \mathrm{ft}^{3} / \mathrm{s}$

Water-surface elevation in bridge opening

$94.4 f t$

Road overtopping? ___ N Discharge over road $-\mathrm{ft}^{3} / \mathrm{s}$

Area of flow in bridge opening

Average velocity in bridge opening

$\frac{53 \boldsymbol{t}^{2}}{9.8}$

Maximum WSPRO tube velocity at bridge $f t / s$

Water-surface elevation at Approach section with bridge

Water-surface elevation at Approach section without bridge

Amount of backwater caused by bridge

1.1 it

500-year discharge $\quad \begin{array}{lll}700 & \mathrm{ft}^{3} / \mathrm{s}\end{array}$

Water-surface elevation in bridge opening

$95.1 f t$

Road overtopping? ___ N Discharge over road

Area of flow in bridge opening

Average velocity in bridge opening 64 $f t^{2}$ $10.9 \mathrm{ft} / \mathrm{s}$

Maximum WSPRO tube velocity at bridge

$13.7 \quad$ s

Water-surface elevation at Approach section with bridge

Water-surface elevation at Approach section without bridge

Amount of backwater caused by bridge

$$
1.5 . t
$$

97.9

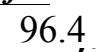

Incipient overtopping discharge ___ -- $\mathrm{ft}^{3} / \mathrm{s}$

Water-surface elevation in bridge opening $\quad--t_{t}$

Area of flow in bridge opening

$-\boldsymbol{f t}^{2}$

Average velocity in bridge opening

Maximum WSPRO tube velocity at bridge $f t^{2}$

$-\quad f t / s$

Water-surface elevation at Approach section with bridge

Water-surface elevation at Approach section without bridge

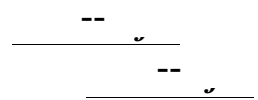
Amount of backwater caused by bridge

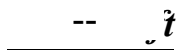




\section{Scour Analysis Summary \\ Special Conditions or Assumptions Made in Scour Analysis}

Scour depths were computed using the general guidelines described in Hydraulic Engineering Circular 18 (Richardson and others, 1995). Scour depths were calculated assuming an infinite depth of erosive material and a homogeneous particle-size distribution. The results of the scour analysis are presented in tables 1 and 2 and a graph of the scour depths is presented in figure 8 .

Contraction scour was computed by use of the clear-water contraction scour equation (Richardson and others, 1995, p. 32, equation 20). Results are presented in figure 8 and tables 1 and 2. The streambed armoring depths computed suggest that armoring will not limit the depth of contraction scour.

Abutment scour was computed by use of the Froehlich equation (Richardson and others, 1995, p. 48, equation 28). Variables for the Froehlich equation include the Froude number of the flow approaching the embankments, the length of the embankment blocking flow, and the depth of flow approaching the embankment less any roadway overtopping. 


\section{Scour Results}

\section{0-yr discharge 500-yr discharge}

Contraction scour:

(Scour depths in feet)

Main channel

Live-bed scour

Clear-water scour

Depth to armoring

Left overbank

Right overbank

Local scour:

Abutment scour

Left abutment

6.1

7.2

$4.6-$

$5.7-$

Right abutment

Pier scour

Pier 1

Pier 2

Pier 3

\section{Abutments:}

Left abutment

Right abutment

Piers:

Pier 1

Pier 2

Incipient overtopping discharge 


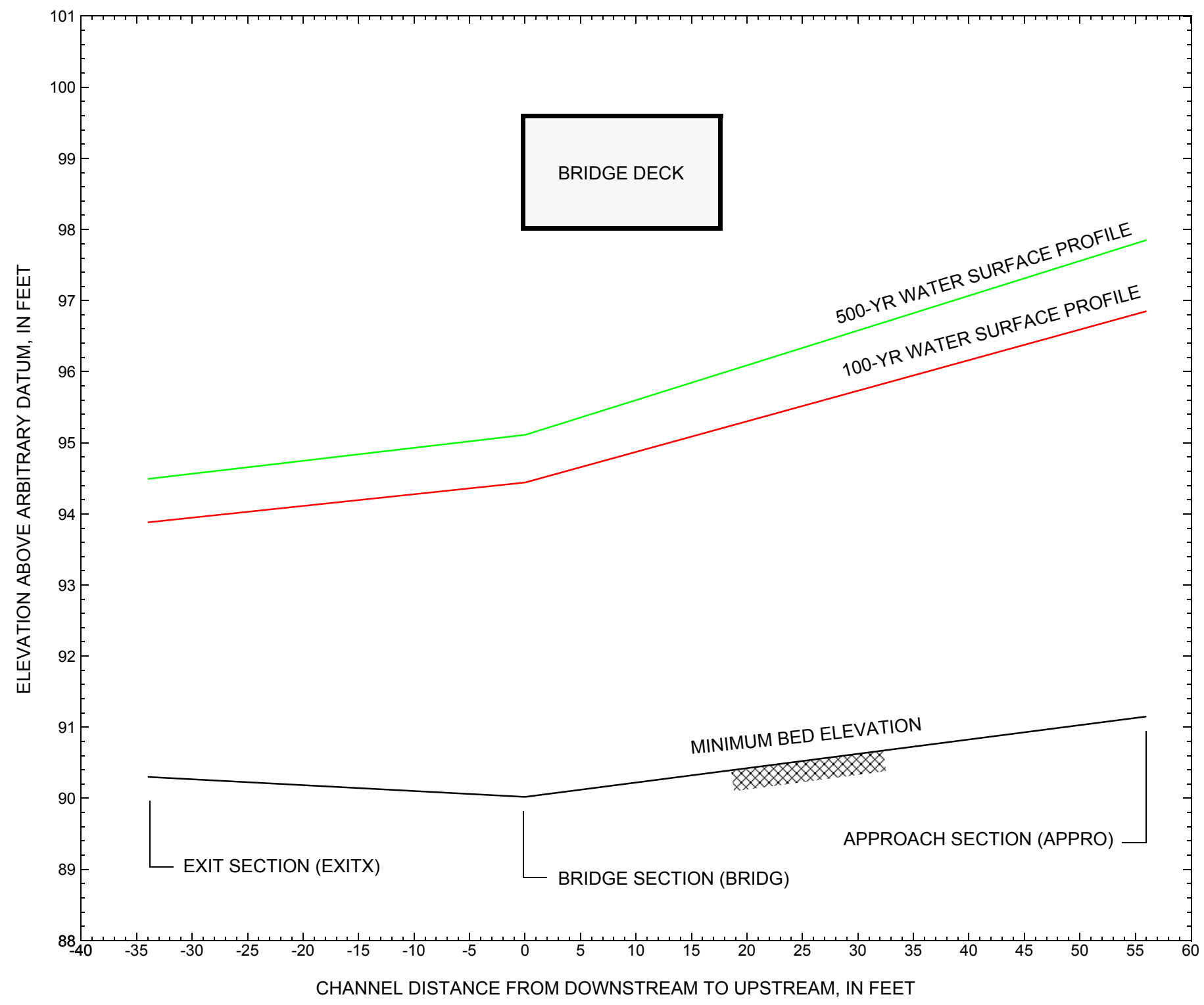

Figure 7. Water-surface profiles for the 100- and 500-yr discharges at structure GLOVTH00410023 on Town Highway 41, crossing Sherburne Brook, Glover, Vermont. 


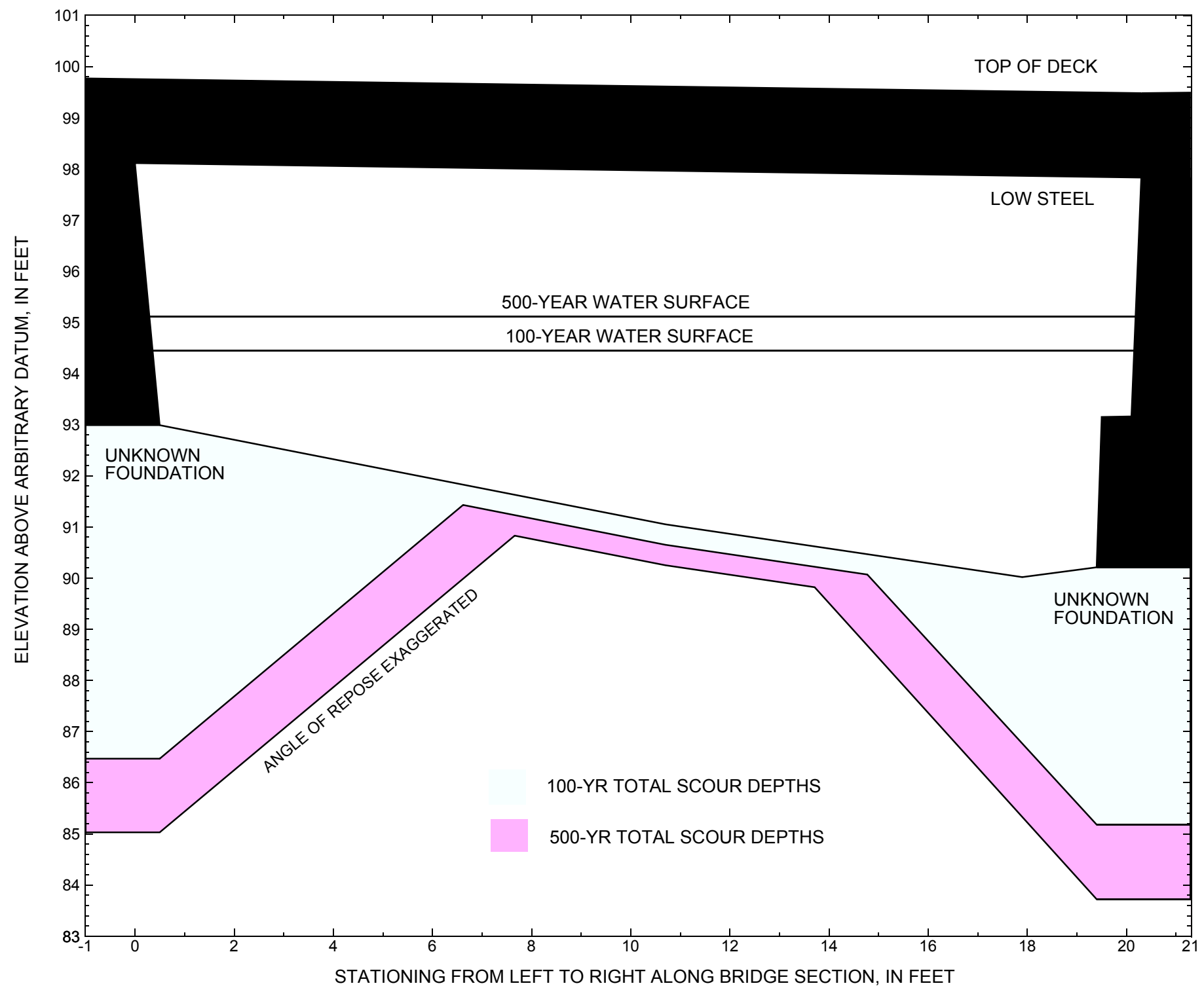

Figure 8. Scour elevations for the 100-yr and 500-yr discharges at structure GLOVTH00410023 on Town Highway 41, crossing Sherburne Brook, Glover, Vermont. 
Table 1. Remaining footing/pile depth at abutments for the 100-year discharge at structure GLOVTH00410023 on Town Highway 41, crossing Sherburne Brook, Glover, Vermont.

[VTAOT, Vermont Agency of Transportation; --,no data]

\begin{tabular}{|c|c|c|c|c|c|c|c|c|c|c|c|}
\hline Description & Station $^{1}$ & $\begin{array}{l}\text { VTAOT } \\
\text { minimum } \\
\text { low-chord } \\
\text { elevation } \\
\text { (feet) }\end{array}$ & $\begin{array}{c}\text { Surveyed } \\
\text { minimum } \\
\text { low-chord } \\
\text { elevation }{ }^{2} \\
\text { (feet) }\end{array}$ & $\begin{array}{c}\text { Bottom of } \\
\text { footing } \\
\text { elevation } \\
\text { (feet) }\end{array}$ & $\begin{array}{c}\text { Channel } \\
\text { elevation at } \\
\text { abutment/ } \\
\text { pier }^{2} \\
\text { (feet) }\end{array}$ & $\begin{array}{l}\text { Contraction } \\
\text { scour depth } \\
\text { (feet) }\end{array}$ & $\begin{array}{l}\text { Abutment } \\
\text { scour } \\
\text { depth } \\
\text { (feet) }\end{array}$ & $\begin{array}{l}\text { Pier } \\
\text { scour } \\
\text { depth } \\
\text { (feet) }\end{array}$ & $\begin{array}{l}\text { Depth of } \\
\text { total scour } \\
\text { (feet) }\end{array}$ & $\begin{array}{c}\text { Elevation of } \\
\text { scour }^{2} \\
\text { (feet) }\end{array}$ & $\begin{array}{c}\text { Remaining } \\
\text { footing/pile } \\
\text { depth } \\
\text { (feet) }\end{array}$ \\
\hline \multicolumn{12}{|c|}{100 -yr. discharge is 515 cubic-feet per second } \\
\hline Left abutment & 0.0 & -- & 98.1 & -- & 93.0 & 0.4 & 6.1 & -- & 6.5 & 86.5 & -- \\
\hline Right abutment & 20.3 & -- & 97.8 & -- & 90.2 & 0.4 & 4.6 & -- & 5.0 & 85.2 & -- \\
\hline
\end{tabular}

1.Measured along the face of the most constricting side of the bridge.

2.Arbitrary datum for this study.

Table 2. Remaining footing/pile depth at abutments for the 500-year discharge at structure GLOVTH00410023 on Town Highway 41, crossing Sherburne Brook, Glover, Vermont.

[VTAOT, Vermont Agency of Transportation; --, no data]

\begin{tabular}{|c|c|c|c|c|c|c|c|c|c|c|c|}
\hline Description & Station $^{1}$ & $\begin{array}{l}\text { VTAOT } \\
\text { minimum } \\
\text { low-chord } \\
\text { elevation } \\
\text { (feet) }\end{array}$ & $\begin{array}{c}\text { Surveyed } \\
\text { minimum } \\
\text { low-chord } \\
\text { elevation } \\
\text { (feet) }\end{array}$ & $\begin{array}{c}\text { Bottom of } \\
\text { footing } \\
\text { elevation } \\
\text { (feet) }\end{array}$ & $\begin{array}{c}\text { Channel } \\
\text { elevation at } \\
\text { abutment/ } \\
\text { pier }^{2} \\
\text { (feet) }\end{array}$ & $\begin{array}{l}\text { Contraction } \\
\text { scour depth } \\
\text { (feet) }\end{array}$ & $\begin{array}{c}\text { Abutment } \\
\text { scour } \\
\text { depth } \\
\text { (feet) }\end{array}$ & $\begin{array}{l}\text { Pier } \\
\text { scour } \\
\text { depth } \\
\text { (feet) }\end{array}$ & $\begin{array}{l}\text { Depth of } \\
\text { total scour } \\
\text { (feet) }\end{array}$ & $\begin{array}{c}\text { Elevation of } \\
\text { scour }^{2} \\
\text { (feet) }\end{array}$ & $\begin{array}{c}\text { Remaining } \\
\text { footing/pile } \\
\text { depth } \\
\text { (feet) }\end{array}$ \\
\hline \multicolumn{12}{|c|}{500 -yr. discharge is 700 cubic-feet per second } \\
\hline Left abutment & 0.0 & -- & 98.1 & -- & 93.0 & 0.8 & 7.2 & -- & 8.0 & 85.0 & -- \\
\hline Right abutment & 20.3 & -- & 97.8 & -- & 90.2 & 0.8 & 5.7 & -- & 6.5 & 83.7 & -- \\
\hline
\end{tabular}

1.Measured along the face of the most constricting side of the bridge.

2.Arbitrary datum for this study. 


\section{SELECTED REFERENCES}

Arcement, G.J., Jr., and Schneider, V.R., 1989, Guide for selecting Manning's roughness coefficients for natural channels and flood plains: U.S. Geological Survey Water-Supply Paper 2339, 38 p.

Barnes, H.H., Jr., 1967, Roughness characteristics of natural channels: U.S. Geological Survey Water-Supply Paper 1849,213 p.

Benson, M. A., 1962, Factors Influencing the Occurrence of Floods in a Humid Region of Diverse Terrain: U.S. Geological Survey WaterSupply Paper 1580-B, 64 p.

Brown, S.A. and Clyde, E.S., 1989, Design of riprap revetment: Federal Highway Administration Hydraulic Engineering Circular No. 11, Publication FHWA-IP-89-016, 156 p.

Federal Highway Administration, 1983, Runoff estimates for small watersheds and development of sound design: Federal Highway Administration Report FHWA-RD-77-158.

Federal Highway Administration, 1993, Stream Stability and Scour at Highway Bridges: Participant Workbook: Federal Highway Administration Report FHWA-HI-91-011.

Froehlich, D.C., 1989, Local scour at bridge abutments in Ports, M.A., ed., Hydraulic Engineering--Proceedings of the 1989 National Conference on Hydraulic Engineering: New York, American Society of Civil Engineers, p. 13-18.

Hayes, D.C.,1993, Site selection and collection of bridge-scour data in Delaware, Maryland, and Virginia: U.S. Geological Survey WaterResources Investigation Report 93-4017, 23 p.

Interagency Advisory Committee on Water Data, 1982, Guidelines for determining flood flow frequency: U.S. Geological Survey, Bulletin 17B of the Hydrology Subcommittee, 190 p.

Johnson, C.G. and Tasker, G.D.,1974, Progress report on flood magnitude and frequency of Vermont streams: U.S. Geological Survey OpenFile Report 74-130, 37 p.

Lagasse, P.F., Schall, J.D., Johnson, F., Richardson, E.V., Chang, F., 1995, Stream Stability at Highway Structures: Federal Highway Administration Hydraulic Engineering Circular No. 20, Publication FHWA-IP-90-014, 144 p.

Laursen, E.M., 1960, Scour at bridge crossings: Journal of the Hydraulics Division, American Society of Civil Engineers, v. 86, no. HY2, p. 39-53.

Potter, W. D., 1957a, Peak rates of runoff in the Adirondack, White Mountains, and Maine woods area, Bureau of Public Roads

Potter, W. D., 1957b, Peak rates of runoff in the New England Hill and Lowland area, Bureau of Public Roads

Richardson, E.V. and Davis, S.R., 1995, Evaluating scour at bridges: Federal Highway Administration Hydraulic Engineering Circular No. 18, Publication FHWA-IP-90-017, 204 p.

Richardson, E.V., Simons, D.B., and Julien, P.Y., 1990, Highways in the river environment: Federal Highway Administration Publication FHWA-HI-90-016.

Ritter, D.F., 1984, Process Geomorphology: W.C. Brown Co., Debuque, Iowa, 603 p.

Shearman, J.O., 1990, User's manual for WSPRO--a computer model for water surface profile computations: Federal Highway Administration Publication FHWA-IP-89-027, 187 p.

Shearman, J.O., Kirby, W.H., Schneider, V.R., and Flippo, H.N., 1986, Bridge waterways analysis model; research report: Federal Highway Administration Publication FHWA-RD-86-108, 112 p.

Talbot, A.N., 1887, The determination of water-way for bridges and culverts.

U.S. Department of Transportation, 1993, Stream stability and scour at highway bridges, Participant Workbook: Federal Highway Administration Publication FHWA HI-91-011.

U.S. Geological Survey, 1986, Crystal Lake, Vermont 7.5 Minute Series quadrangle map: U.S. Geological Survey Topographic Maps, Scale $1: 24,000$. 


\section{APPENDIX A: \\ WSPRO INPUT FILE}




\section{WSPRO INPUT FILE}

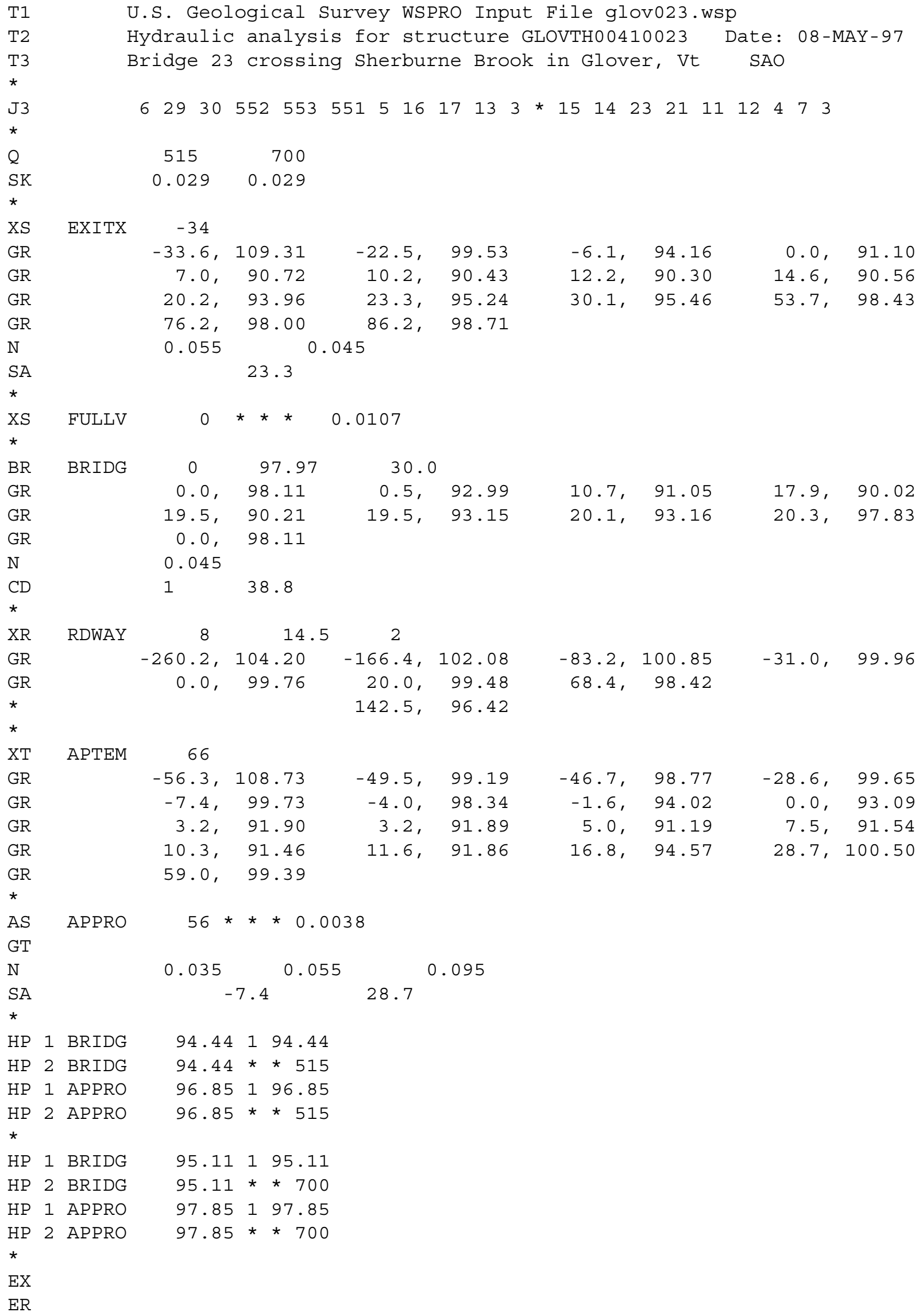




\section{APPENDIX B: \\ WSPRO OUTPUT FILE}


WSPRO OUTPUT FILE

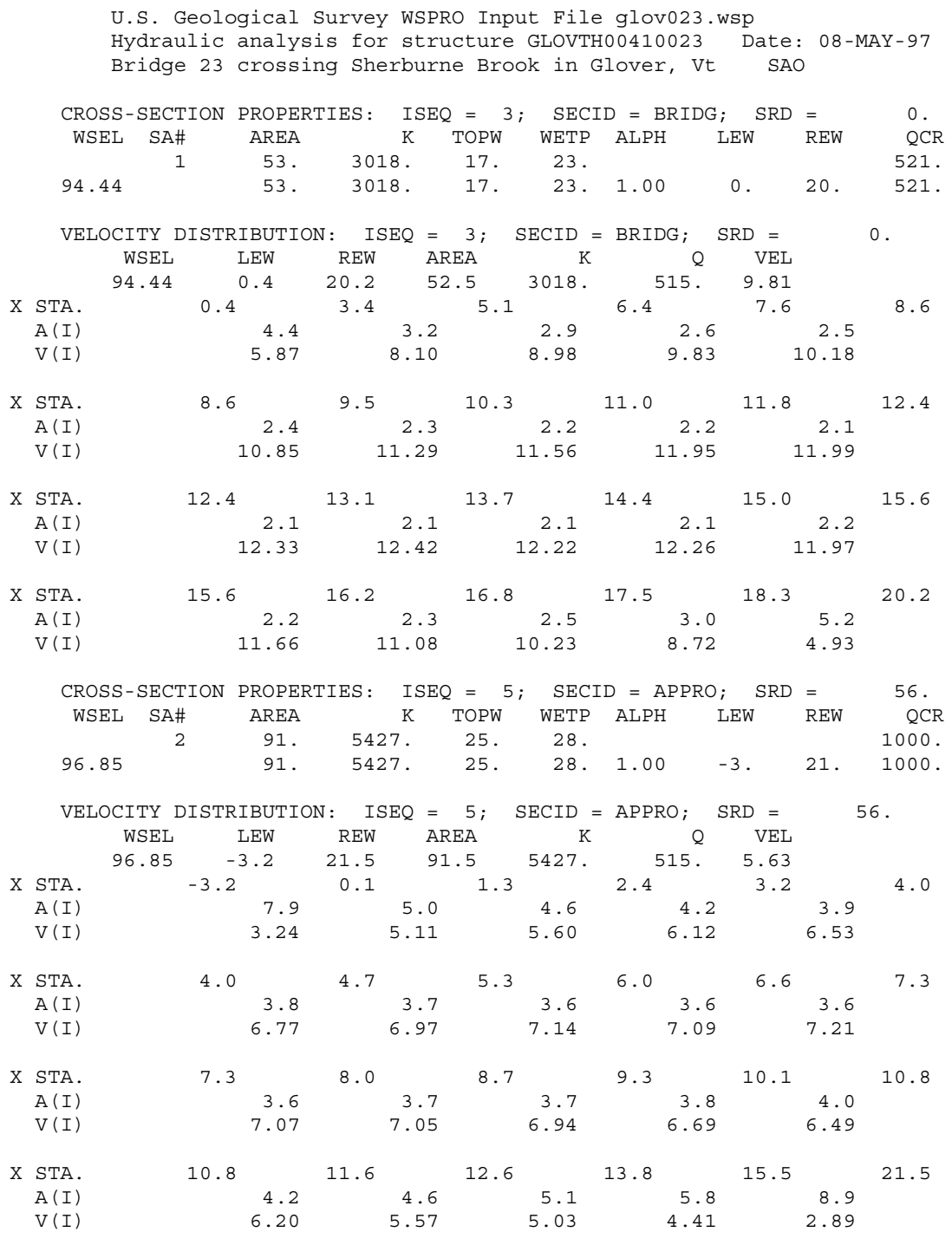


WSPRO OUTPUT FILE (continued)

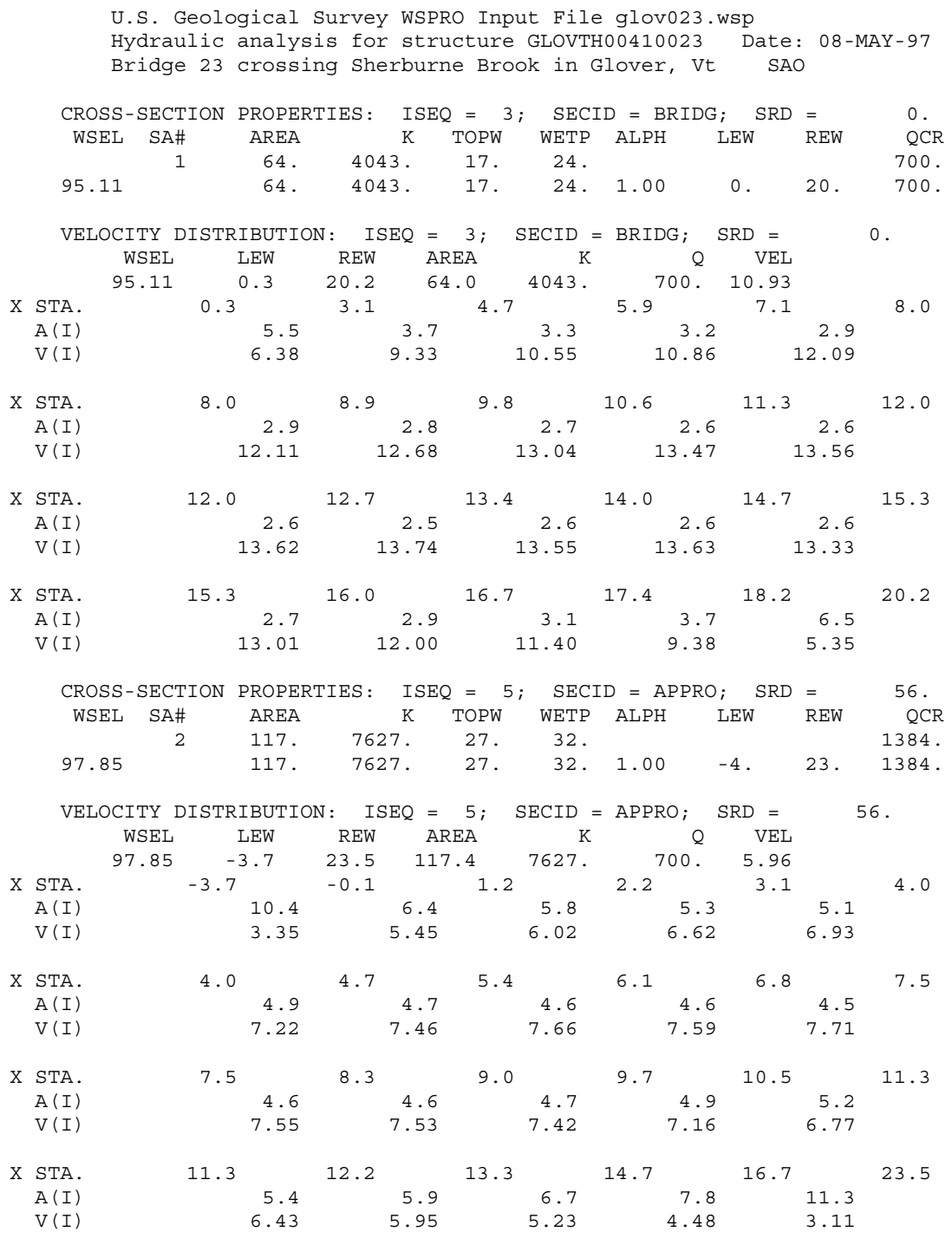


WSPRO OUTPUT FILE (continued)

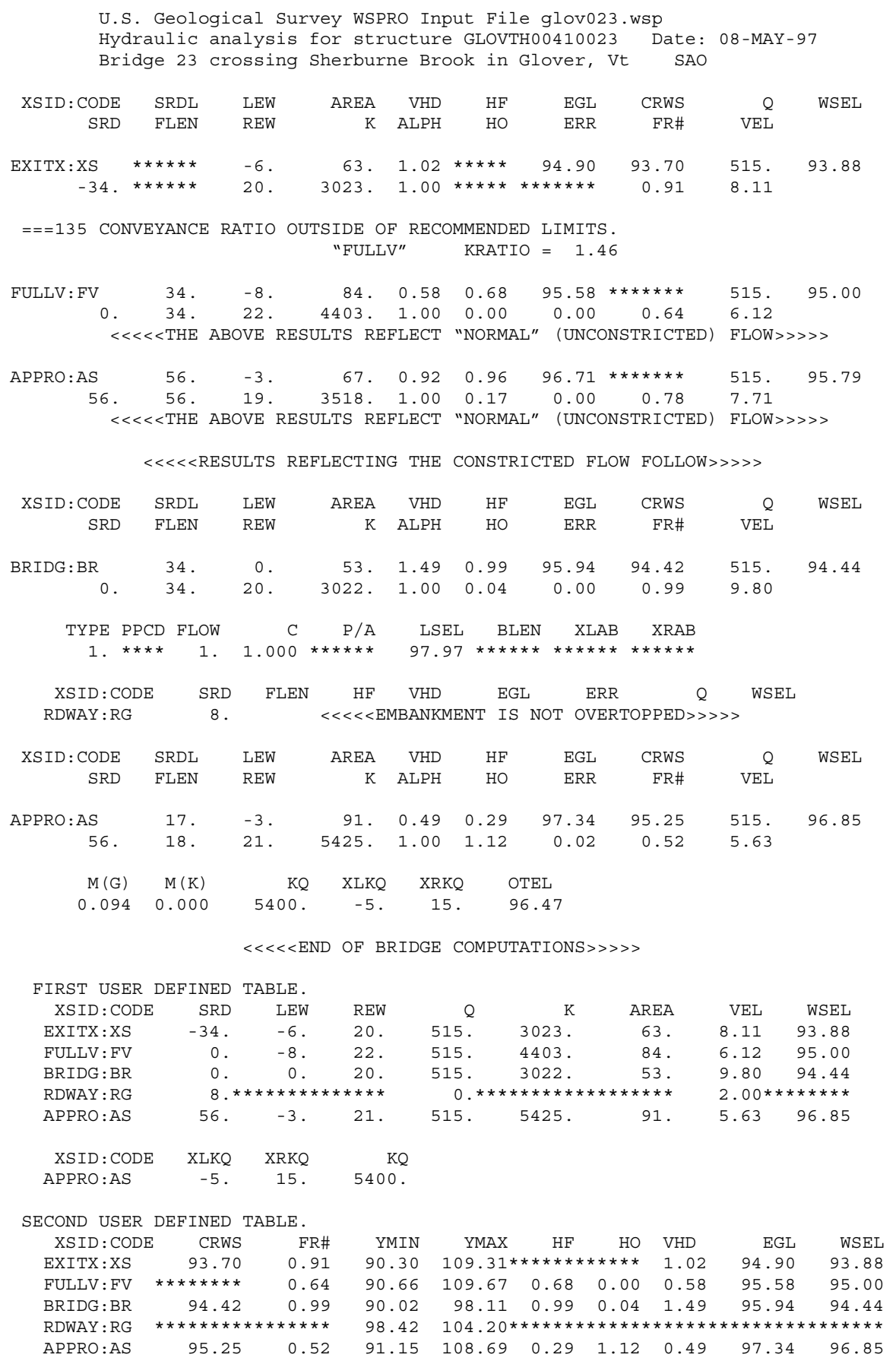


WSPRO OUTPUT FILE (continued)

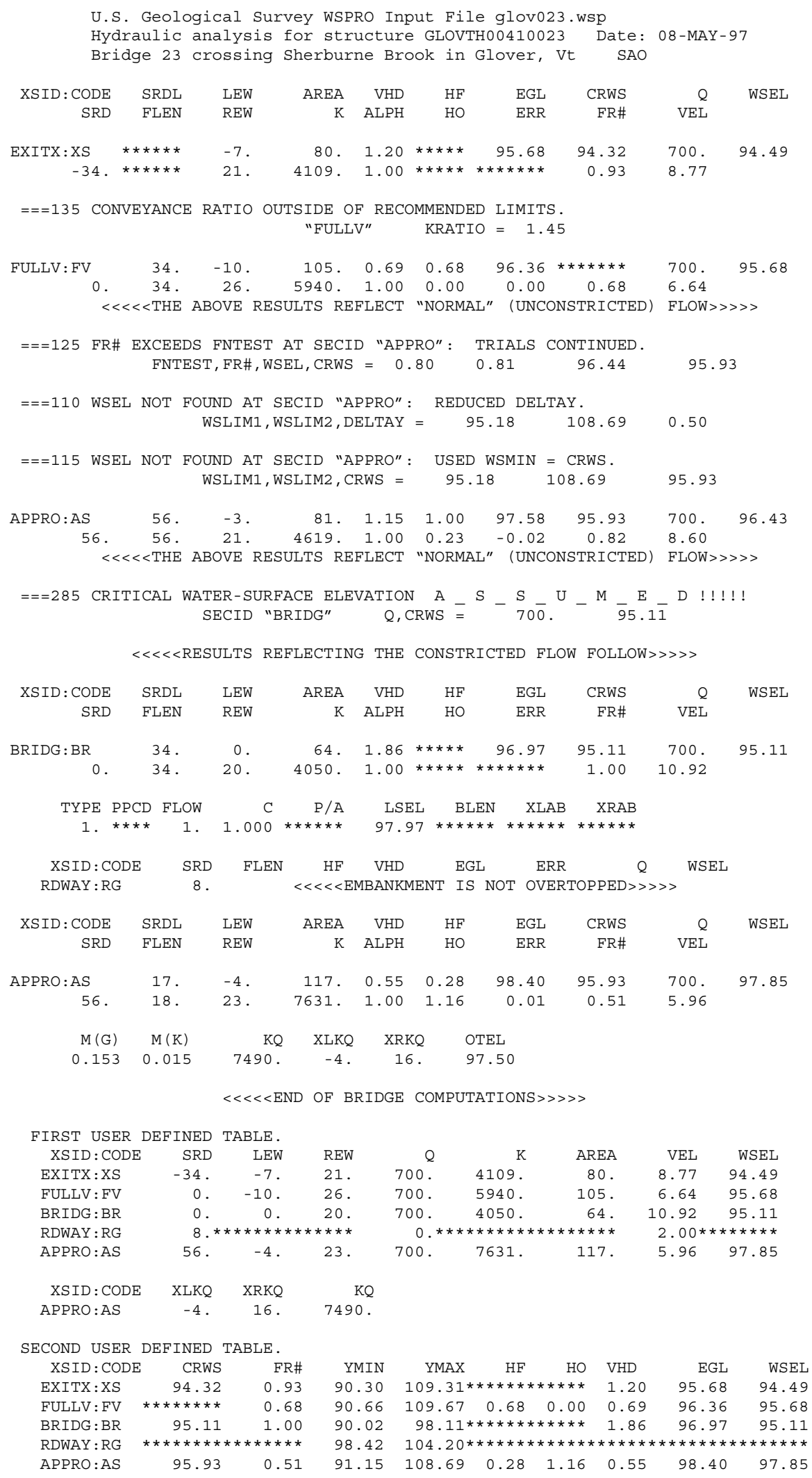




\section{APPENDIX C:}

\section{BED-MATERIAL PARTICLE-SIZE DISTRIBUTION}




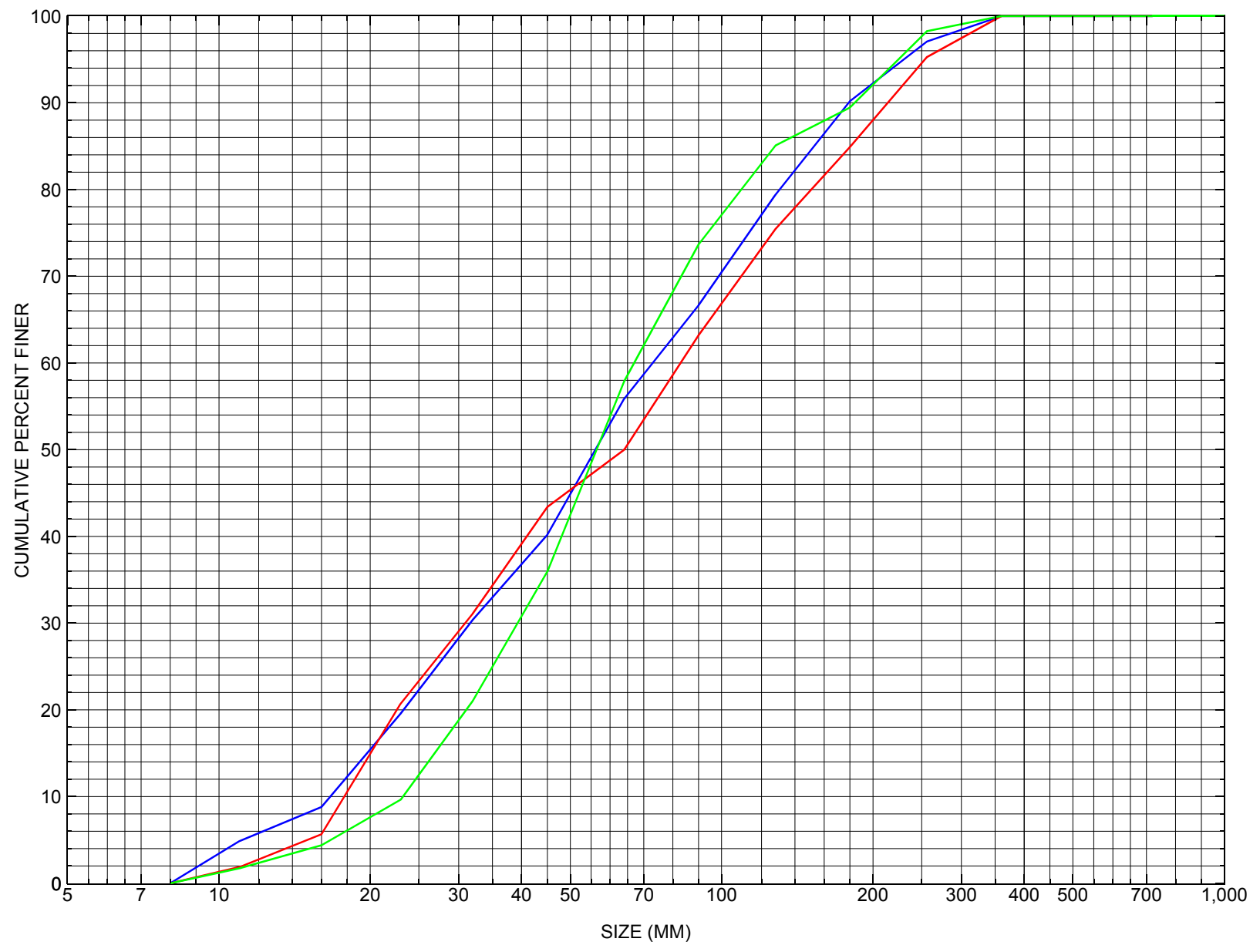

Appendix C. Bed material particle-size distribution for three pebble count transects in the channel approach of structure GLOVTH00410023, in Glover, Vermont. 


\section{APPENDIX D: \\ HISTORICAL DATA FORM}




\section{Structure Number GLOVTH00410023}

\section{General Location Descriptive}

Data collected by (First Initial, Full last name) M. WEBER

Date $(M M / D D / Y Y) \_\mathbf{0 8} / \underline{\mathbf{0 4}} / \underline{\mathbf{9 4}}$

Highway District Number (I - 2; nn) 09

Town (FIPS place code; I - 4; nnnnn) $\mathbf{2 8 0 7 5}$

Waterway (I - 6) SHERBURNE BROOK

Route Number $\mathbf{0 . 1}$ MI

Topographic Map Crystal.Lake

Latitude (I - 16; nnnn.n) $\mathbf{4 4 4 0 8}$
County (FIPS county code; I - 3; nnn)

Mile marker (I - 11; nnn.nnn) $\mathbf{0 0 0 0 0 0}$

Road Name (I - 7): TH041

Vicinity (I - 9) TO JCT W VT16

Hydrologic Unit Code: $\mathbf{0 1 1 1 0 0 0 0}$

Longitude (i - 17; nnnnn.n) 72113

\section{Select Federal Inventory Codes}

FHWA Structure Number (I - 8) $\mathbf{1 0 1 0 0 8 0 0 2 3 1 0 0 8}$

Maintenance responsibility $(I-21 ; n n) \quad \mathbf{0 3}$

Year built (I - 27; YYYY) 1919

Average daily traffic, ADT (I - 29; nnnnnn) 000050

Year of ADT (I - 30; YY) $\mathbf{9 1}$

Opening skew to Roadway $(I-34 ; n n) \quad \mathbf{4 0}$

Operational status $(I-41 ; X) \underline{\mathbf{A}}$

Structure type (I- 43; nnn) $\mathbf{3 0 2}$

Approach span structure type (I - 44; nnn) $\mathbf{0 0 0}$

Number of spans (I - 45; nnn) $\mathbf{0 0 1}$

Number of approach spans (I - 46; nnnn) $\mathbf{0 0 0 0}$

Comments:

Structural inspection of 7/9/93 indicates a steel stringer with timber deck bridge. A minor amount of mortar is missing on both abutment walls. The footing is exposed at the right abutment. No undermining or settlement. No embankment erosion. The channel makes sharp bend through bridge. A point bar along left abutment blocks $50 \%$ of the flow. The deck is in poor condition. Some scour at the right abutment if any.
Maximum span length (I - 48; nnnn) $\underline{\mathbf{0 0 2 1}}$

Structure length (I - 49; nnnnnn) $\underline{\mathbf{0 0 0 0 2 4}}$

Deck Width (I - 52; nn.n) 145

Channel \& Protection $(I-61 ; n) \underline{6}$

Waterway adequacy $(I-71 ; n) \underline{8}$

Underwater Inspection Frequency $(I-92 B ; X Y Y) \_$N

Year Reconstructed (I - 106) $\mathbf{0 0 0 0}$

Clear span (nnn.n ft) _

Vertical clearance from streambed (nnn.n ft) $\underline{\mathbf{0 0 7 . 5}}$

Waterway of full opening (nnn.n $\left.\mathrm{ft}^{2}\right)$ 


\section{Bridge Hydrologic Data}

Is there hydrologic data available? $\underline{\mathbf{Y}}$ if No, type ctrl-n $h \quad$ VTAOT Drainage area $\left(\mathrm{mi}^{2}\right)^{2}: \underline{\mathbf{1 . 4}}$

Terrain character:

Stream character \& type: -

Streambed material: Stones and boulders with gravel and mud

Discharge Data (cfs): $\quad Q_{2.33}-$

$$
\mathrm{Q}_{50} \mathbf{4 2 0}
$$

$\mathrm{Q}_{10} \frac{\mathbf{2 9 0}}{\mathbf{5 0 0}}$

$Q_{25} \mathbf{3 5 0}$

$Q_{500}$

Record flood date $(M M / D D / Y Y):-1 /$

Estimated Discharge (cfs):

Velocity at $\mathrm{Q}$ -

Water surface elevation (ft): -

Ice conditions (Heavy, Moderate, Light) : Light

Debris (Heavy, Moderate, Light): Moderate

The stage increases to maximum highwater elevation (Rapidly, Not rapidly):

The stream response is (Flashy, Not flashy):

Describe any significant site conditions upstream or downstream that may influence the stream's stage: -

Watershed storage area (in percent): _ _ \%

The watershed storage area is: - (1-mainly at the headwaters; 2- uniformly distributed; 3-immediatly upstream oi the site)

Water Surface Elevation Estimates for Existing Structure:

\begin{tabular}{|l|l|l|l|l|l|}
\hline Peak discharge frequency & $Q_{2.33}$ & $Q_{10}$ & $Q_{25}$ & $Q_{50}$ & $Q_{100}$ \\
Water surface elevation (ft) $)$ & - & $\mathbf{5 . 6}$ & $\mathbf{6 . 6}$ & $\mathbf{7 . 6}$ & $\mathbf{9 . 1}$ \\
Velocity $(\mathrm{ft} / \mathrm{sec})$ & - & - & $\mathbf{1 2 . 1}$ & - & - \\
\hline
\end{tabular}

Long term stream bed changes: -

Is the roadway overtopped below the $\mathrm{Q}_{100}$ ? (Yes, No, Unknown): $\mathbf{Y} \quad$ Frequency: $\underline{\mathbf{Q 5 0}}$

Relief Elevation $(f t)$ :

Discharge over roadway at $Q_{100}\left(f t^{3} / \mathrm{sec}\right)$ :

Are there other structures nearby? (Yes, No, Unknown): Upstream distance (miles): Town: If No or Unknown, type ctrl-n os Highway No. : Structure No. : Year Built:

Clear span (ft): Clear Height (ft): Full Waterway $\left(f t^{2}\right)$ : 
Downstream distance (miles): Town: Year Built:

Highway No. : Structure No. : Structure Type:

Clear span (ft): Clear Height $(f t)$ : Full Waterway $\left(f^{2}\right)$ :

Comments:

The above high water elevations are measured up from the ambient channel bed.

\section{USGS Watershed Data}

Watershed Hydrographic Data

Drainage area $(D A)$

Watershed storage (ST) $\mathrm{mi}^{2}$ Lake/pond/swamp area 0.10 $\mathrm{mi}^{2}$

Bridge site elevation 1221 3.4 $\%$

Main channel length $\mathbf{2 . 8 0}$ $\mathrm{ft}$ Headwater elevation 2188 $\mathrm{ft}$ $10 \%$ channel length elevation $\quad \mathbf{1 2 7 0}$ $\mathrm{ft} \quad 85 \%$ channel length elevation 1850 $\mathrm{ft}$

Main channel slope (S) $\mathbf{2 7 6 . 3 2} \mathrm{ft} / \mathrm{mi}$

Watershed Precipitation Data

Average site precipitation in Average headwater precipitation in

Maximum 2yr-24hr precipitation event $(124,2)$ in

Average seasonal snowfall (Sn) $\mathrm{ft}$ 


\section{Bridge Plan Data}

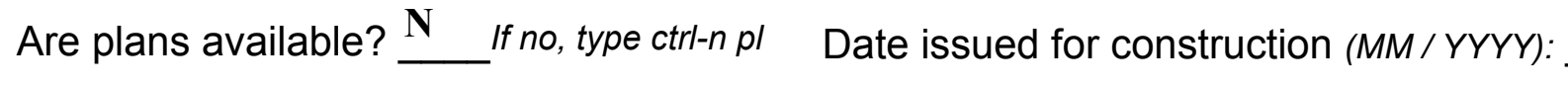

Project Number

Minimum channel bed elevation:

Low superstructure elevation: USLAB DSLAB USRAB DSRAB Benchmark location description:

Reference Point (MSL, Arbitrary, Other): Datum (NAD27, NAD83, Other):

Foundation Type: 4

If 1 : Footing Thickness

If 2: Pile Type: (1-Wood; 2-Steel or metal; 3-Concrete)

If 3 : Footing bottom elevation:

Is boring information available? $\mathbf{N}$ Foundation Material Type: $\mathbf{3}$ (1-Spreadfooting; 2-Pile; 3- Gravity; 4-Unknown) Footing bottom elevation: -

Briefly describe material at foundation bottom elevation or around piles:

NO FOUNDATION MATERIAL INFORMATION

Comments:

NO PLANS. 


\section{Cross-sectional Data}

Is cross-sectional data available? $\mathbf{N}$ If no, type ctrl-n xs

Source (FEMA, VTAOT, Other)? -

Comments:

\section{NO CROSS SECTION INFORMATION}

\begin{tabular}{|l|l|l|l|l|l|l|l|l|l|l|l|}
\hline Station & - & - & - & - & - & - & - & - & - & - & - \\
\hline Feature & - & - & - & - & - & - & - & - & - & - & - \\
\hline $\begin{array}{l}\text { Low cord } \\
\text { elevation }\end{array}$ & - & - & - & - & - & - & - & - & - & - & - \\
\hline $\begin{array}{l}\text { Bed } \\
\text { elevation }\end{array}$ & - & - & - & - & - & - & - & - & - & - & - \\
\hline $\begin{array}{l}\text { Low cord to } \\
\text { bed length }\end{array}$ & - & - & - & - & - & - & - & - & - & - & - \\
\hline Station & - & - & - & - & - & - & - & - & - & - & - \\
\hline Feature & - & - & - & - & - & - & - & - & - & - & - \\
\hline $\begin{array}{l}\text { Low cord } \\
\text { elevation }\end{array}$ & - & - & - & - & - & - & - & - & - & - & - \\
\hline $\begin{array}{l}\text { Bed } \\
\text { elevation }\end{array}$ & - & - & - & - & - & - & - & - & - & - & - \\
\hline $\begin{array}{l}\text { Low cord to } \\
\text { bed length }\end{array}$ & - & - & - & - & - & - & - & - & - & - & - \\
\hline
\end{tabular}

Source (FEMA, VTAOT, Other)?

Comments: NO CROSS SECTION INFORMATION

\begin{tabular}{|l|l|l|l|l|l|l|l|l|l|l|l|}
\hline Station & - & - & - & - & - & - & - & - & - & - & - \\
\hline Feature & - & - & - & - & - & - & - & - & - & - & - \\
\hline $\begin{array}{l}\text { Low cord } \\
\text { elevation }\end{array}$ & - & - & - & - & - & - & - & - & - & - & - \\
\hline $\begin{array}{l}\text { Bed } \\
\text { elevation }\end{array}$ & - & - & - & - & - & - & - & - & - & - & - \\
\hline $\begin{array}{l}\text { Low cord to } \\
\text { bed length }\end{array}$ & - & - & - & - & - & - & - & - & - & - & - \\
\hline Station & - & - & - & - & - & - & - & - & - & - & - \\
\hline Feature & - & - & - & - & - & - & - & - & - & - & - \\
\hline $\begin{array}{l}\text { Low cord } \\
\text { elevation }\end{array}$ & - & - & - & - & - & - & - & - & - & - & - \\
\hline $\begin{array}{l}\text { Bed } \\
\text { elevation }\end{array}$ & - & - & - & - & - & - & - & - & - & - & - \\
\hline $\begin{array}{l}\text { Low cord to } \\
\text { bed length }\end{array}$ & - & - & - & - & - & - & - & - & - & - & - \\
\hline
\end{tabular}




\section{APPENDIX E: \\ LEVEL I DATA FORM}


U. S. Geological Survey

Bridge Field Data Collection and Processing Form

Qa/Qc Check by: DLS Date: 2/6/95

\section{Structure Number}

\section{A. General Location Descriptive}

1. Data collected by (First Initial, Full last name) E. BOEHMLER

Date $(M M / D D / Y Y)$

$10 / 24$

/ 1994

2. Highway District Number 09

County ORLEANS (019)

Mile marker -

Waterway (I - 6) SHERBURNE BROOK

Town GLOVER (28075)

Route Number TH41

Road Name -

3. Descriptive comments:

Hydrologic Unit Code: $\mathbf{0 1 1 1 0 0 0 0}$

The structure is a steel stringer type bridge located about 0.2 miles from the intersection of TH41 with

VT16. The bridge has a timber deck with grey painted steel pipe guard rails.

\section{B. Bridge Deck Observations}
4. Surface cover... LBUS 6
RBUS 6
LBDS 6
RBDS 6
Overall 6

(2b us,ds,lb,rb: 1- Urban; 2- Suburban; 3- Row crops; 4- Pasture; 5- Shrub- and brushland; 6- Forest; 7- Wetland)
5. Ambient water surface... US 2
UB 1
DS 2
(1- pool; 2- riffle)

6. Bridge structure type 1 (1- single span; 2- multiple span; 3- single arch; 4- multiple arch; 5-cylindrical culvert; 6- box culvert; or 7- other)
7. Bridge length 24.0
(feet)
Span length $\mathbf{2 1 . 0}$
(feet)
Bridge width 14.5 (feet)

\section{Road approach to bridge:}
8. LB 0
RB 0
( 0 even, 1- lower, 2- higher)
9. LB_2
RB $\underline{2}$
(1-Paved, 2- Not paved)

10. Embankment slope (run / rise in feet / foot)

US left

US right

\begin{tabular}{|c|c|c|c|}
\hline \multicolumn{2}{|c|}{ Protection } & \multirow{2}{*}{ 13.Erosion } & 14.Severity \\
\hline 11.Type & 12.Cond. & - & $\underline{\mathbf{1}}$ \\
\hline $\mathbf{0}$ & - & $\mathbf{0}$ & $\mathbf{0}$ \\
\hline $\mathbf{0}$ & - & $\underline{\mathbf{2}}$ & $\underline{\mathbf{2}}$ \\
\hline $\mathbf{0}$ & - & $\mathbf{2}$ & $\mathbf{1}$ \\
\hline $\mathbf{0}$ & - & $\underline{\mathbf{2}}$ & $\mathbf{-}$ \\
\hline
\end{tabular}

Bank protection types: 0- none; 1- < 12 inches;

2- $<36$ inches; $3-<48$ inches;

4- < 60 inches; 5- wall / artificial levee

Bank protection conditions: 1- good; 2- slumped;

3- eroded; 4- failed

Erosion: 0 - none; 1- channel erosion; 2 -

road wash; 3- both; 4- other

Erosion Severity: 0 - none; 1- slight; 2- moderate; 3- severe

\section{Channel approach to bridge (BF):}

15. Angle of approach: $\mathbf{2 0}$

16. Bridge skew: $\mathbf{5 5}$

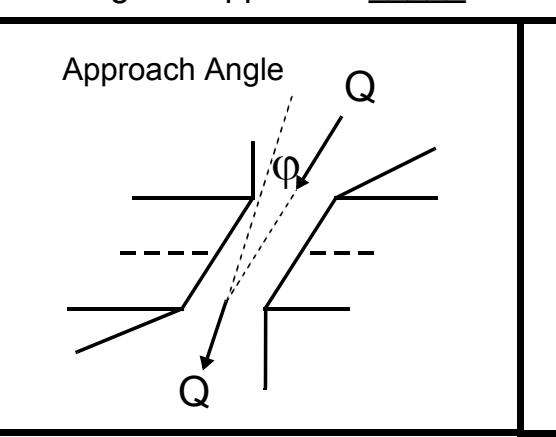

17. Channel impact zone 1 :

Where? RB (LB, RB) Bridge Skew Angle

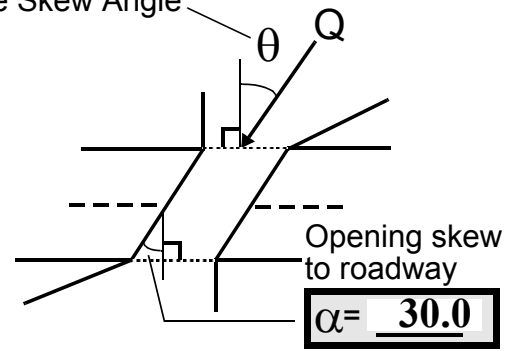

Range? 25 feet US (US,

Channel impact zone 2:

Where? LB (LB, RB)

Exist? $\mathbf{Y}(Y$ or $N)$

Range? $\underline{80}$ feet $\underline{\mathbf{U S}}$

Severity 1

Exist? $\mathbf{Y}(Y$ or $N)$

Severity 3

$U B, D S)$ to $\underline{\mathbf{1 0}}$ feet $\underline{\mathbf{U S}}$

mpact Severity: 0- none to very slight; 1- Slight; 2- Moderate; 3- Severe 
18. Bridge Type: $1 \mathbf{b}$

1a- Vertical abutments with wingwalls

1 b- Vertical abutments without wingwalls

2- Vertical abutments and wingwalls, sloping embankment Wingwalls perpendicular to abut. face

3- Spill through abutments

4- Sloping embankment, vertical wingwalls and abutments
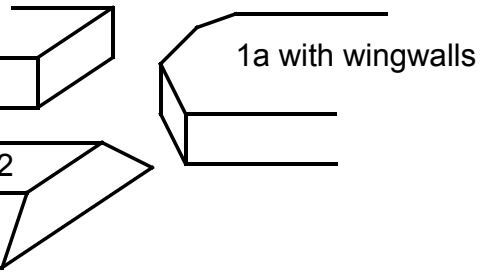

Wingwall angle less than $90^{\circ}$.

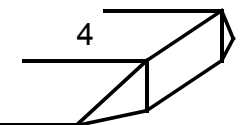

19. Bridge Deck Comments (surface cover variations, measured bridge and span lengths, bridge type variations, approach overflow width, etc.)

The measured bridge length is $\mathbf{2 3 . 0}$ feet, while the other dimensions are the same as those indicated on the historical form.

Surface cover on the immediate left bank upstream is the gravel roadway with forest further away from the channel. On the right bank upstream, there is a home surrounded by a lawn, but the predominant surface cover is still forest. The downstream right bank has a grass plot, otherwise it is forested. The downstream left bank surface cover is brush to about 25 feet downstream where it changes to forest cover.

The upstream left bank is impacted moderately as the channel bends and runs along the immediate edge of the roadway for 150 feet before turning sharply to proceed under the bridge. The upstream end of the bridge has vertical retaining walls extending upstream from both abutment walls.

\section{Upstream Channel Assessment}

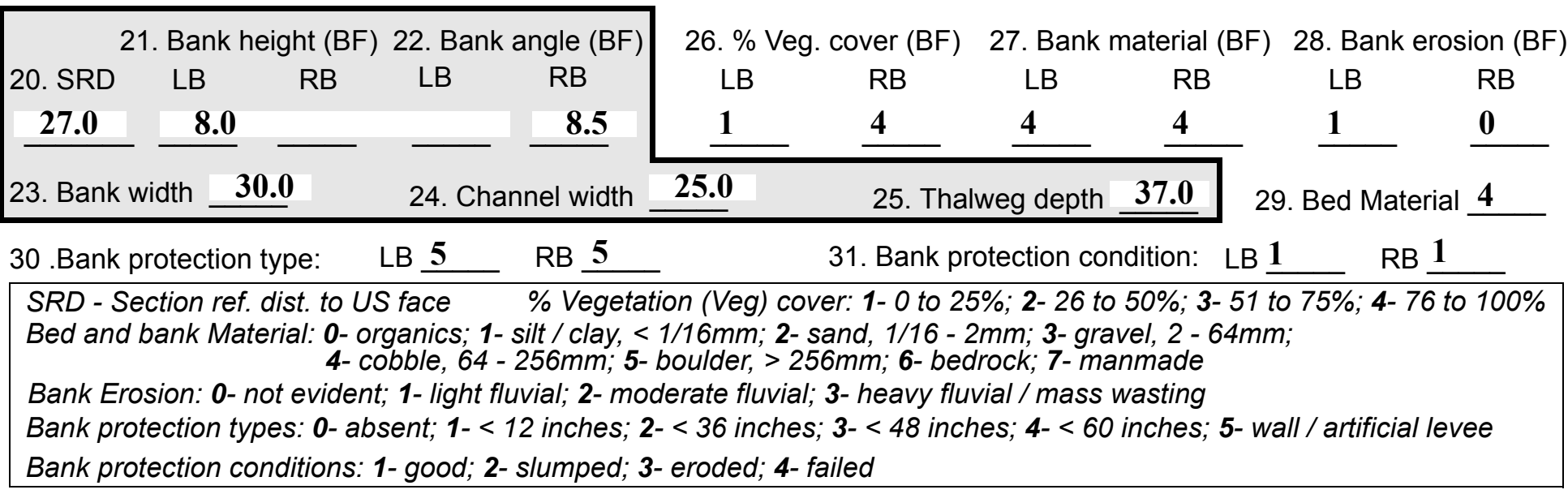

32. Comments (bank material variation, minor inflows, protection extent, etc.):

The banks are composed of cobble and boulder material with fill for the roadway on top on the left bank upstream. Cobble and boulder material in the right bank is in a sand matrix with a lot of organics (leaves, branches, etc.) on top and a thin topsoil layer. The bed material appears to have a high fraction of coarse gravel, cobbles, and some boulders embedded in a coarse sand and fine gravel.

30. The abutments extend upstream 31 feet on the right and 11 feet on the left. These abutment extensions are being considered as bank protection in this case. The right abutment is experiencing undermining. 
37. Material: 3

38. Point or side bar comments (Circle Point or Side; Note additional bars, material variation, status, etc.):

The point bar material ranges from coarse gravel at the upstream end to fine gravel and coarse to medium sand under the bridge, to coarse gravel and cobbles at the downstream end.

39. Is a cut-bank present? $\mathbf{Y}$ (Y or if $N$ type ctrl-n $c b)$

41. Mid-bank distance: $\mathbf{6 5}$

43. Bank damage: 1

42. Cut bank extent: 80

40. Where? $\underline{\mathbf{L B}}$ (LB or RB) feet $\underline{\mathbf{U S}}$ (US, UB) to $\underline{\mathbf{5 0}}$ feet $\underline{\mathbf{U S}}$ (US, UB, DS) (1- eroded and/or creep; 2- slip failure; 3- block failure)

44. Cut bank comments (eg. additional cut banks, protection condition, etc.):

The entire left bank upstream is moderately eroded with only small (1 to 2 year old) trees. The roots are exposed on some of the young trees and some are leaning toward the channel. Some slight bank undercutting is evident in various places along the bank. The bank material here is very steep and loose and eroding and creeping down the embankment.

45. Is channel scour present? $\mathbf{N}$ ( $Y$ or if $N$ type ctrl-n cs)

47. Scour dimensions: Length Width Depth : 46. Mid-scour distance: -

48. Scour comments (eg. additional scour areas, local scouring process, etc.):

NO CHANNEL SCOUR

49. Are there major confluences? $\mathbf{N}$

51. Confluence 1: Distance Confluence 2: Distance -

Confluence 2: Distance

54. Confluence comments (eg. confluence name):

NO MAJOR CONFLUENCES
(Y or if $N$ type ctrl-n mc)

52. Enters on -

Enters on ( $L B$ or $R B$ ) ( $L B$ or $R B)$
50. How many? -

53. Type(1- perennial; 2- ephemeral)

Type (1- perennial; 2-ephemeral)
55. Channel restraint (BF)? LB 2

\begin{tabular}{|ccccc}
\hline \multicolumn{2}{c}{ 56. Height (BF) } & \multicolumn{2}{c}{57 Angle (BF) } \\
LB & RB & LB & RB \\
$\mathbf{8 . 5}$ & & & $\mathbf{0 . 5}$ & \\
\hline
\end{tabular}

\section{Under Bridge Channel Assessment}

58. Bank width (BF) -

59. Channel width $(A m b)$

61. Material (BF)

LB RB

$\underline{2} \quad \underline{7}$

\section{Erosion (BF)}

LB RB

7

63. Bed Material -

Bed and bank Material: 0- organics; 1- silt / clay, < 1/16mm; 2- sand, 1/16 - 2mm; 3- gravel, 2 - 64mm; 4- cobble, 64 - 256mm; 5- boulder, > 256mm; 6- bedrock; 7- manmade

Bank Erosion: 0- not evident; 1- light fluvial; 2- moderate fluvial; 3- heavy fluvial / mass wasting

64. Comments (bank material variation, minor inflows, protection extent, etc.):

4

The streambed is covered with cobbles and boulders at the thalweg which runs along the right abutment but is fine gravel and coarse to medium sand along the left abutment. 
65. Debris and Ice Is there debris accumulation?

67. Debris Potential (1- Low; 2- Moderate; 3- High)

69. Is there evidence of ice build-up? $\underline{3}(Y$ or $N)$

70. Debris and Ice Comments:

2

A fallen tree is in the channel along the downstream left bank parallel with the direction of flow. Remnants of the tree are too long to have flowed through the bridge. There are a lot of small branches and small trees that have accumulated along the banks upstream. However, no distinct zones are apparent where debris has piled up.

\begin{tabular}{|l|c|c|c|c|c|c|c|c|}
\hline Abutments & $\begin{array}{c}\text { 71. Attack } \\
\angle \text { (BF) }\end{array}$ & $\begin{array}{c}\text { 72. Slope } \angle \\
\text { (Qmax) }\end{array}$ & $\begin{array}{c}\text { 73. Toe } \\
\text { loc. (BF) }\end{array}$ & $\begin{array}{c}\text { 74. Scour } \\
\text { Condition }\end{array}$ & $\begin{array}{c}\text { 75. Scour } \\
\text { depth }\end{array}$ & $\begin{array}{c}\text { 76. Exposure } \\
\text { depth }\end{array}$ & 77. Material & 78. Length \\
\hline LABUT & & - & $\mathbf{9 0}$ & $\mathbf{0}$ & $\mathbf{0}$ & - & - & $\mathbf{9 0 . 0}$ \\
\hline RABUT & $\mathbf{2}$ & $\mathbf{1 5}$ & $\mathbf{9 0}$ & & & $\mathbf{2}$ & $\mathbf{3}$ & $\mathbf{2 0 . 5}$ \\
\hline
\end{tabular}

Pushed: $L B$ or RB

Toe Location (Loc.): 0- even, 1- set back, 2- protrudes

Scour cond.: 0- not evident; 1- evident (comment); 2- footing exposed; 3-undermined footing; 4- piling exposed; 5- settled; 6- failed

Materials: 1- Concrete; 2- Stone masonry or drywall; 3- steel or metal; 4- wood

79. Abutment comments (eg. undermined penetration, unusual scour processes, debris, etc.):

1.0

3.5

2

The right abutment footing is undermined about 0.5 feet (vertical) and a rangepole penetrates in some spots to a maximum of one foot (horizontal). The exposure depth above (3.5 ft) refers to the maximum measurement from the top of the footing to the stream bed. The retaining wall footing on the right bank upstream also is exposed at least by 2 to 3.5 feet, with the undermining restricted to the location of the wall just upstream of the abutment wall. On the left bank, the retaining wall is in good condition except for the extreme upstream end where it is being eroded from behind the wall probably by both channel and roadwash processes. The attack angle shown is focused primarily on the right bank retaining wall/upstream end of abutment. The right abut-

80. Wingwalls:
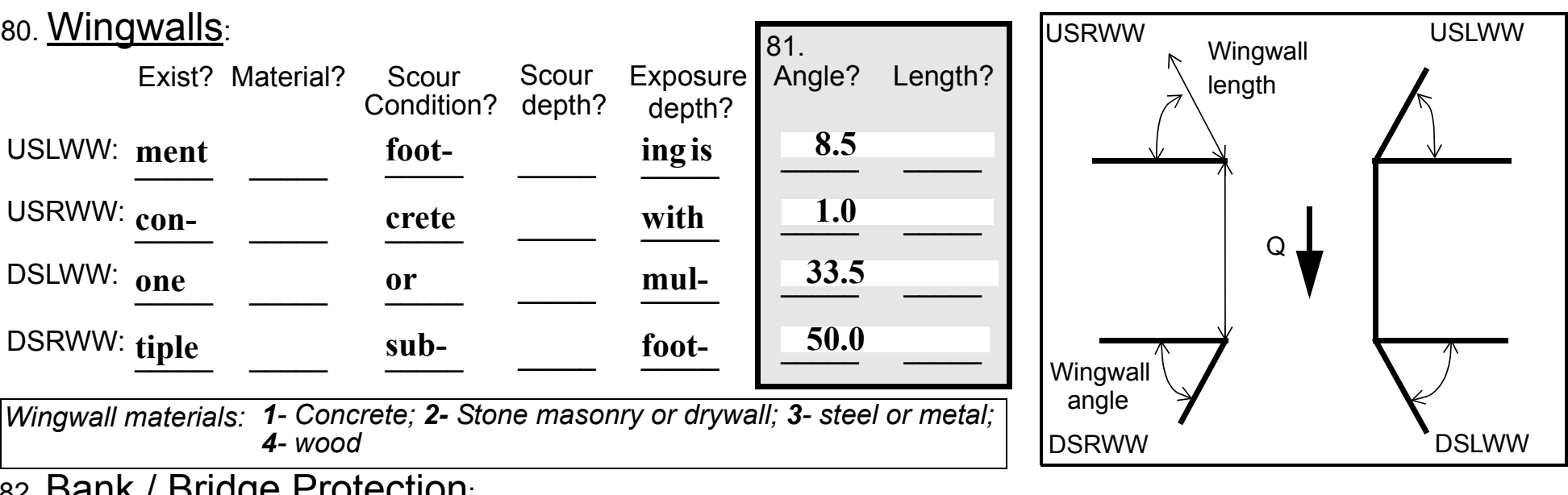

82. Bank / Bridge Protection:

\begin{tabular}{|l|l|l|l|l|l|l|l|l|}
\hline Location & USLWW & USRWW & LABUT & RABUT & LB & RB & DSLWW & DSRWW \\
\hline Type & ing ( & ed & peri & cha & sion & the & wall & viou \\
\hline Condition & s) & afte & ods & nnel & belo & ston & or & sly \\
\hline Extent & plac & r & of & ero- & w & e & pre- & inst \\
\hline
\end{tabular}

Bank / Bridge protection types: 0- absent; 1- < 12 inches; 2- < 36 inches; 3- < 48 inches; 4- < 60 inches; 
83. Wingwall and protection comments (eg. undermined penetration, unusual scour processes, etc.): alled subfooting.

N
-
-
-
-
-

\section{Piers:}

84. Are there piers? _ _ (Y or if $N$ type ctrl-n pr)

\begin{tabular}{|l|l|l|l|l|l|l|l|}
\hline \multirow{2}{*}{$\begin{array}{l}85 . \\
\text { Pier no. }\end{array}$} & \multicolumn{3}{|c|}{ width (w) feet } & \multicolumn{3}{c|}{ elevation (e) feet } \\
\cline { 2 - 8 } & w1 & w2 & w3 & e@w1 & e@w2 & e@w3 \\
\hline Pier 1 & - & - & - & - & - & - \\
\hline Pier 2 & - & - & - & - & - & - \\
\hline Pier 3 & - & - & - & - & - & - \\
\hline Pier 4 & - & - & - & - & - & - \\
\hline
\end{tabular}

\begin{tabular}{|c|c|c|c|c|}
\hline Level 1 Pier Descr. & 1 & 2 & 3 & 4 \\
\hline 86. Location (BF) & $\mathbf{N}$ & - & - & \\
\hline 87. Type & - & - & - & \\
\hline 88. Material & - & - & - & \\
\hline 89. Shape & - & - & - & \\
\hline 90. Inclined? & - & $\mathbf{0}$ & - & \\
\hline 91. Attack $\angle(\mathrm{BF})$ & $\mathbf{N}$ & - & - & \\
\hline 92. Pushed & - & - & - & \\
\hline 93. Length (feet) & - & - & - & - \\
\hline 94. \# of piles & - & $\mathbf{0}$ & - & \\
\hline 95. Cross-members & - & - & - & \\
\hline 96. Scour Condition & - & - & - & $\mathbf{N}$ \\
\hline 97. Scour depth & - & - & & - \\
\hline 98. Exposure depth & - & - & & - \\
\hline
\end{tabular}

LFP, LTB, LB, MCL, MCM, MCR, RB, RTB, RFP

1- Solid pier, 2-column, 3- bent

1-Wood; 2-concrete; 3- metal; 4- stone

1- Round; 2- Square; 3- Pointed

Y-yes; $N$ - no

$L B$ or $R B$

0- none; 1- laterals; 2- diagonals; 3- both

0- not evident; 1- evident (comment);

2- footing exposed; 3- piling exposed;

4- undermined footing; 5- settled; 6-failed 
99. Pier comments (eg. undermined penetration, protection and protection extent, unusual scour processes, etc.):

-
-
-
-
-
-
-
-
-

100.

\section{E. Downstream Channel Assessment}

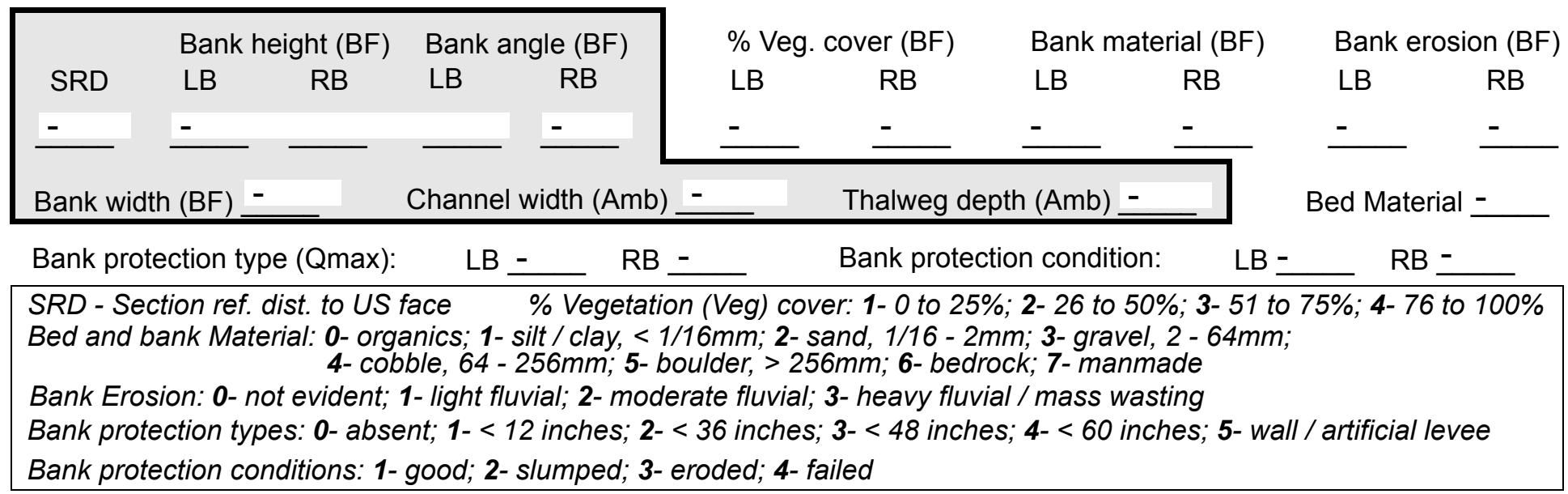

Comments (eg. bank material variation, minor inflows, protection extent, etc.):

$-$

$-$

-

$-$

$-$

$-$

$-$

$-$

$-$

$-$

$-$

$-$

$-$

$-$

$-$

101. Is a drop structure present? _ ( $Y$ or $N$, if $N$ type ctrl-n ds) 102. Distance: ___ feet 103. Drop: __ feet 104. Structure material: ___ (1- steel sheet pile; 2- wood pile; 3- concrete; 4- other) 105. Drop structure comments (eg. downstream scour depth):

$-$

$-$

$-$

$-$

$-$

$-$ 
106. Point/Side bar present? (Y or $N$. if $N$ type ctrl-n pb)Mid-bar distance:

Point bar extent: $\underline{\text { PIE }}$ feet $\underline{\mathbf{R S}}$ (US, UB, DS) to feet (US, UB, DS) positioned $\%$ LB to $\% R B$

Material:

Point or side bar comments (Circle Point or Side; note additional bars, material variation, status, etc.):

$\underline{\text { Is a cut-bank present? }} \underline{\mathbf{2}}$ (Y or if $N$ type ctrl- $n$ cb) Where? $\underline{\mathbf{1}}$ (LB or RB) Mid-bank distance: $\underline{\mathbf{3}}$ Cut bank extent: 3 feet 2 (US, UB, DS) to 1 feet 4 (US, UB, DS)

Bank damage: $\mathbf{0}$ (1- eroded and/or creep; 2- slip failure; 3- block failure)

Cut bank comments (eg. additional cut banks, protection condition, etc.): o

$-$

The bank material is composed of more coarse gravel downstream than upstream with some cobbles and

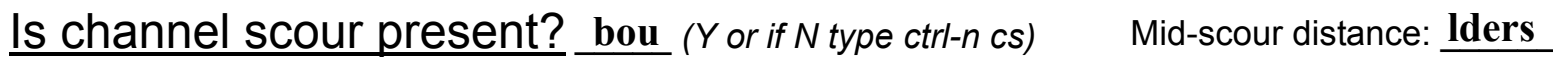
Scour dimensions: Length $\underline{\text { emb }}$ Width edde Depth: $\underline{\mathbf{d} \text { in }} \quad$ Positioned $\underline{\mathbf{a}} \%$ LB to me \%RB Scour comments (eg. additional scour areas, local scouring process, etc.):

dium to coarse sand and fine gravel.

The bed material is similar, but has more cobble material.

Are there major confluences? (Y or if $N$ type ctrl-n $m c)$

How many?

Confluence 1: Distance Enters on (LB or $R B)$

Type (1-perennial; 2- ephemeral)

Confluence 2: Distance Enters on (LB or $R B)$

Type (1-perennial; 2- ephemeral)

Confluence comments (eg. confluence name):

\section{F. Geomorphic Channel Assessment}

107. Stage of reach evolution $\mathbf{N}$

1- Constructed

2- Stable

3- Aggraded

4- Degraded

5- Laterally unstable

6- Vertically and laterally unstable 
108. Evolution comments (Channel evolution not considering bridge effects; See HEC-20, Figure 1 for geomorphic descriptors):

-

NO DROP STRUCTURE

$\mathbf{Y}$

90

8

65

DS

105 


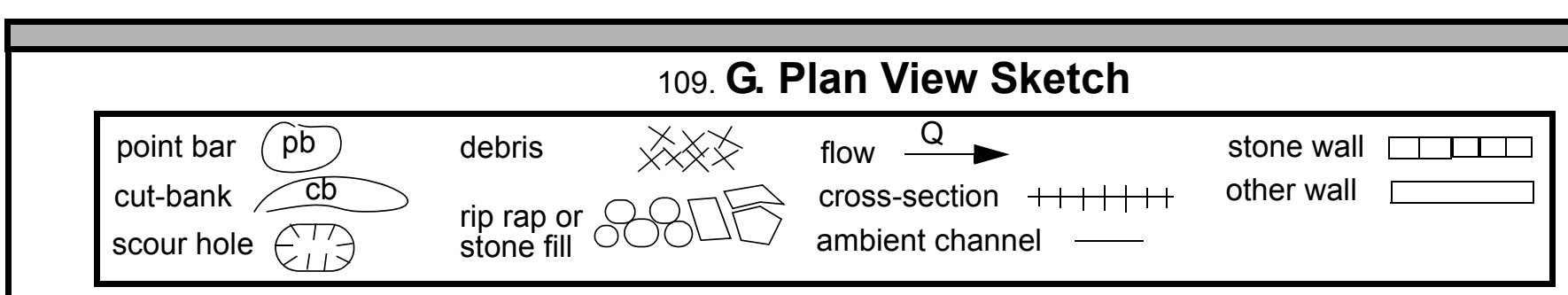


APPENDIX F:

SCOUR COMPUTATIONS 


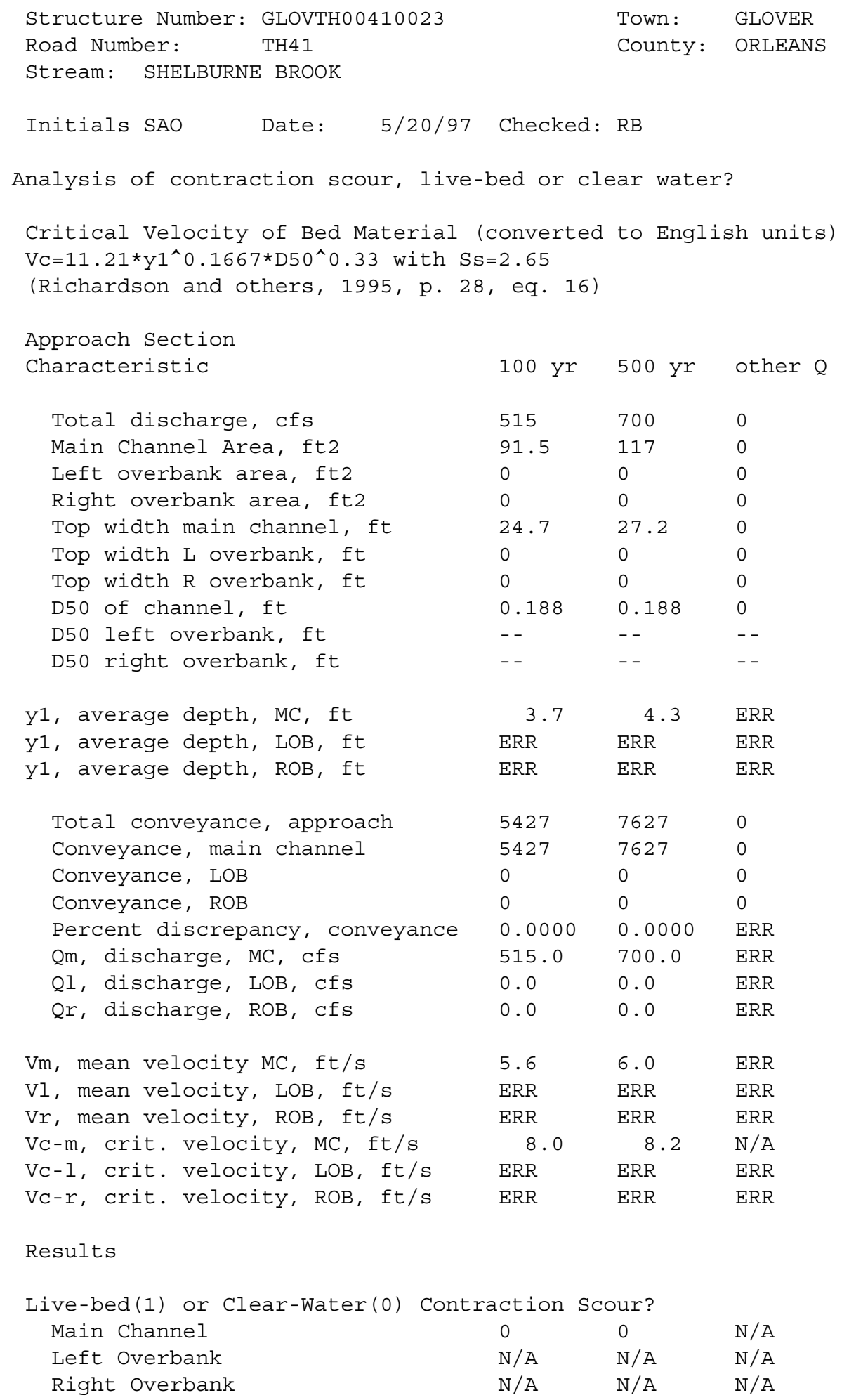


Clear water Contraction Scour in MAIN CHANNEL

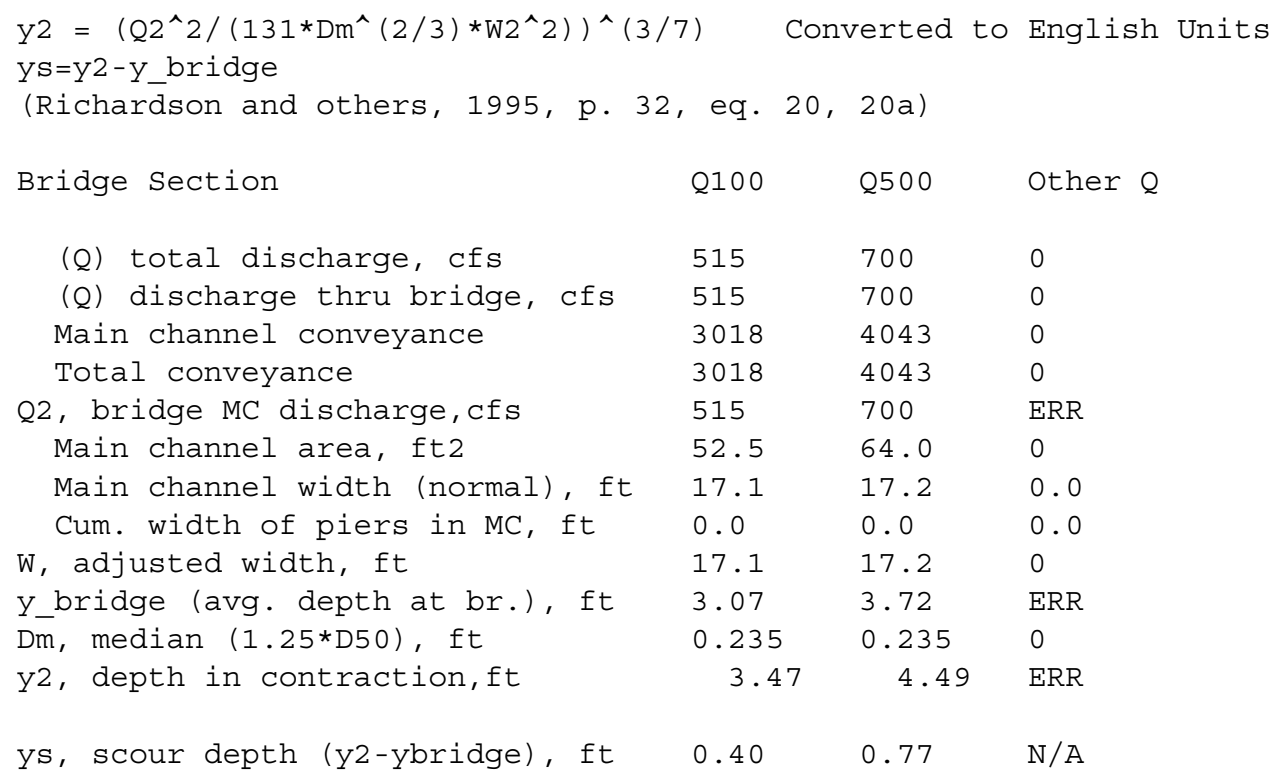

\begin{tabular}{|c|c|c|c|}
\hline \multicolumn{4}{|c|}{$\begin{array}{l}\mathrm{DC}=\left[\left(1.94 * \mathrm{~V}^{\wedge} 2\right) /(5.75 * \log (12.27 * \mathrm{Y} / \mathrm{D} 90))^{\wedge} 2\right] /[0.03 *(165-62.4)] \\
\text { Depth to Armoring }=3 *(1 / \mathrm{PC}-1) \\
\text { (Federal Highway Administration, 1993) }\end{array}$} \\
\hline Downstream bridge face property & $100-y r$ & $500-y r$ & Other Q \\
\hline Q, discharge thru bridge $\mathrm{MC}$, cfs & 515 & 700 & $\mathrm{~N} / \mathrm{A}$ \\
\hline Main channel area (DS), ft2 & 52.5 & 64 & 0 \\
\hline Main channel width (normal), ft & 17.1 & 17.2 & 0.0 \\
\hline Cum. width of piers, ft & 0.0 & 0.0 & 0.0 \\
\hline Adj. main channel width, ft & 17.1 & 17.2 & 0.0 \\
\hline D90, ft & 0.6352 & 0.6352 & 0.0000 \\
\hline D95, ft & 0.7779 & 0.7779 & 0.0000 \\
\hline Dc, critical grain size, ft & 0.5835 & 0.6616 & ERR \\
\hline Pc, Decimal percent coarser than Dc & 0.121 & 0.090 & 0.000 \\
\hline to armoring, ft & 12.73 & 20.08 & ERR \\
\hline
\end{tabular}


Abutment Scour

Froehlich's Abutment Scour

$\mathrm{Ys} / \mathrm{Y} 1=2.27 * \mathrm{~K} 1 * \mathrm{~K} 2 *\left(\mathrm{a}^{\prime} / \mathrm{Y} 1\right) \wedge 0.43 * \mathrm{Fr} 1 \wedge 0.61+1$

(Richardson and others, 1995, p. 48, eq. 28)

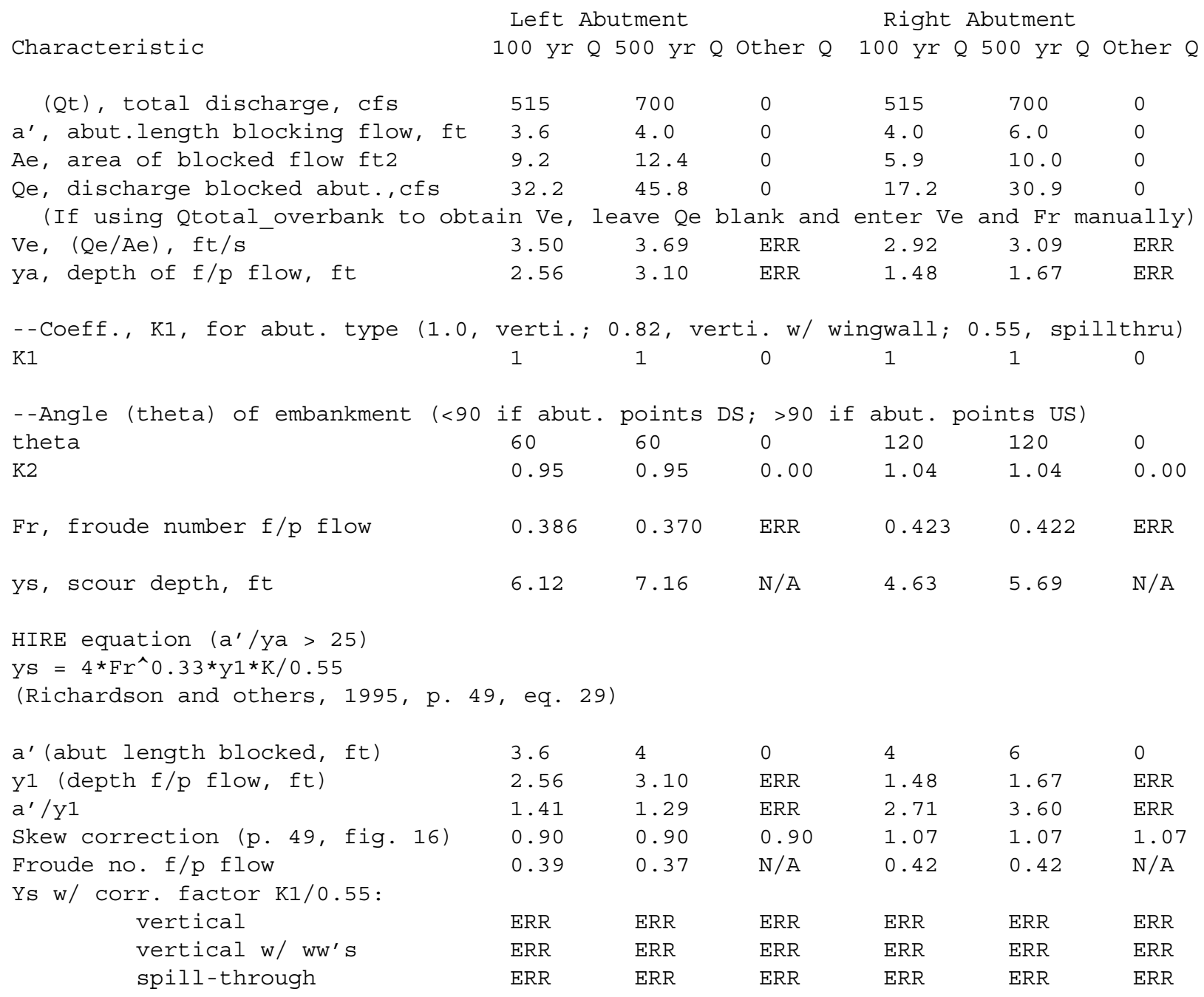




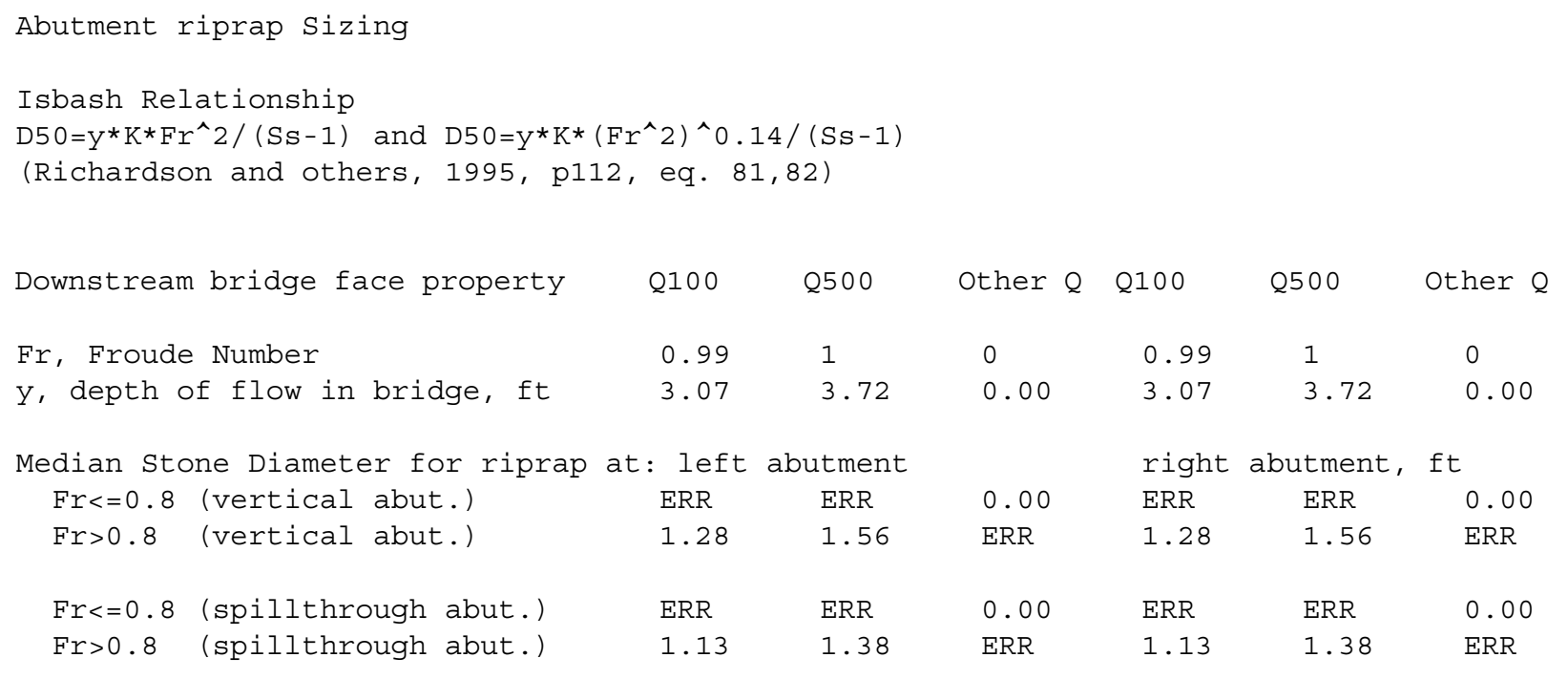

